University of Louisville

ThinkIR: The University of Louisville's Institutional Repository

Electronic Theses and Dissertations

$5-2012$

\title{
Alternative performances of race and gender in hip-hop music : nerdcore counterculture.
}

Jessica Elizabeth Ronald

University of Louisville

Follow this and additional works at: https://ir.library.louisville.edu/etd

\section{Recommended Citation}

Ronald, Jessica Elizabeth, "Alternative performances of race and gender in hip-hop music : nerdcore counterculture." (2012). Electronic Theses and Dissertations. Paper 1231.

https://doi.org/10.18297/etd/1231

This Master's Thesis is brought to you for free and open access by ThinkIR: The University of Louisville's Institutional Repository. It has been accepted for inclusion in Electronic Theses and Dissertations by an authorized administrator of ThinkIR: The University of Louisville's Institutional Repository. This title appears here courtesy of the author, who has retained all other copyrights. For more information, please contact thinkir@louisville.edu. 


\title{
ALTERNATIVE PERFORMANCES OF RACE AND GENDER IN HIP-HOP MUSIC:
}

\section{NERDCORE COUNTERCULTURE}

\section{By}

Jessica Elizabeth Ronald

B.A., Women's and Gender Studies 2008

M.A., Women's and Gender Studies 2010

\author{
A Thesis \\ Submitted to the Faculty of the \\ College of Arts and Sciences of the University of Louisville \\ in Partial Fulfillment of the Requirements \\ for the Degree of
}

Master of Arts

Department of Pan African Studies

University of Louisville

Louisville, Kentucky

May 2012 
ALTERNATIVE PERFORMANCES OF RACE AND GENDER IN HIP-HOP MUSIC:

NERDCORE COUNTERCULTURE

\author{
By
}

Jessica Ronald

B.A., Women's and Gender Studies 2008

M.A., Women's and Gender Studies 2010

A Thesis Approved on

April 18, 2012

by the following Thesis Committee:

Dr. Ricky Jones

Thesis Director

Dr.Kaila Story

Dr. W. S. Tkweme

Dr. David Owen 


\section{DEDICATION}

This thesis is dedicated to

Dr. Diane Pecknold,

who provided the space to research nerdy things

and

Missy Elliot,

who taught me how to work it. 


\section{ACKNOWLEDMENTS}

I would like to thank Dr. Kaila Story for overseeing this entire project throughout the years. I would also like to express immense gratitude to Dr. David Owen for his guidance and patience with the revision process. I am very appreciative of the time and consideration of the other committee members, Dr. W.S. Tkweme and Dr. Ricky Jones. 


\section{ABSTRACT \\ ALTERNATIVE PERFORMANCES OF RACE AND GENDER IN HIP-HOP MUSIC: NERDCORE COUNTERCULTURE}

Jessica E. Ronald

April 18, 2012

In his documentary entitled, Nerdcore For Life, director Dan Lamoureux described Nerdcore as a "powerful social collision between hip hop and geek culture". Born on the Internet, Nerdcore Hip-Hop is rap music made by geeks, for geeks and covers such traditionally "nerdy" topics such as comic books, video games, science fiction, anime, technology, etc. Though it has existed online for almost a decade, only recently has Nerdcore gone from being an Internet fad to an underground cultural phenomenon. This paper investigated how hegemonic constructions of race and gender within both the dominant public sphere and hip-hop culture are subverted and reinvented within Nerdcore counterculture.

The "birth" narrative of the Nerdcore movement, as depicted in film documentaries Nerdcore For Life and Nerdcore Rising, provides a public platform for self-proclaimed nerds to assert cultural power and agency through hip hop music—even while the performance of white, nerdy masculinity, made all the more nerdy by contrast with mainstream hip hop's machismo, subverts that power. The Nerdcore genre has created a transgressive space within the underground hip-hop movement in which marginalized geek culture can claim ownership of an identity alternative to mainstream 
expectations of gender and race. The content of Nerdcore differentiates itself from mainstream hip-hop by speaking to the heart of "geek" culture, but also utilizes hiphop'sability to express the oppressed experiences of today's youth. Nerdcore challenges the traditional misogynistic, hyper-masculine mainstream construction associated with both white and black masculinities, and offers a safe space in which to perform alternative masculinities.

Nerdcore artists offer a unique new strategy for achieving authenticity as white performers in hip-hop counterculture-a conscious subversion. The geek identity presented by Nerdcore does not attempt to recreate gender and racial stereotypes visible in hip-hop nor does it parody hip-hop culture. Nerdcore performers have developed a space to offer a conscious narrative of subversion for alternative identity performances in hip-hop music. 
TABLE OF CONTENTS

PAGE

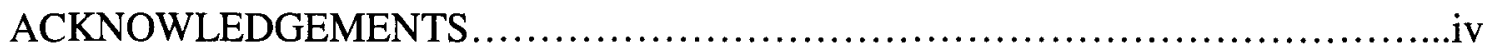

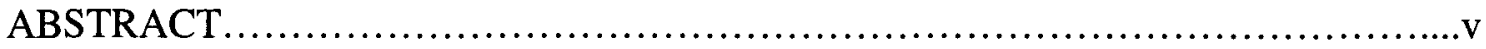

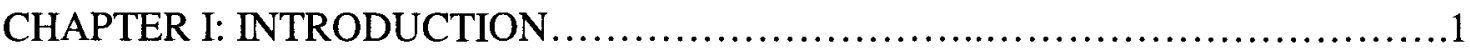

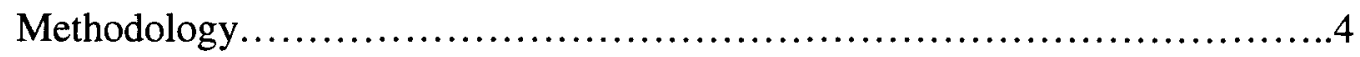

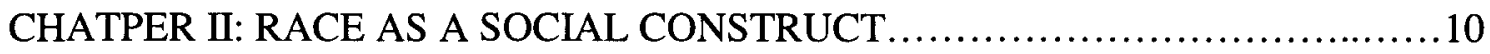

The Hyperwhite Identity ..................................................20

CHAPTER III: HIP-HOP HISTORY ...........................................24

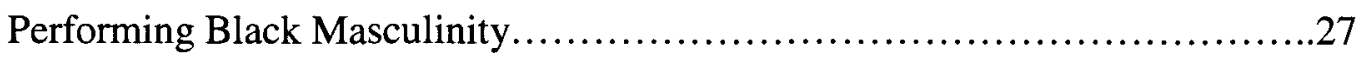

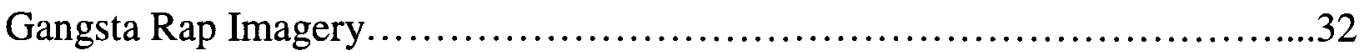

CHAPTER IV: CULTURAL POLITICS OF PARODY, MINSTRELSY, AND

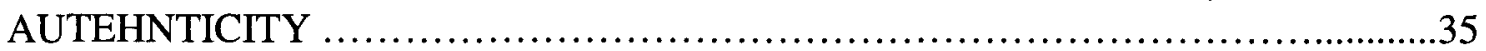

White Appropriation of Black Culture.........................................35

White Rappers "Keepin it Real"... or not...................................39

CHAPTER V: REVENGE OF THE NERDS ......................................45

Nerd Culture's Challenges to Hegemonic Identity............................46

Nerd Identities in Nerdcore.....................................................51

Socially Conscious Music Movements....................................57

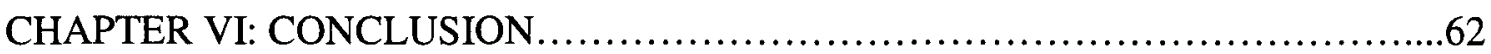

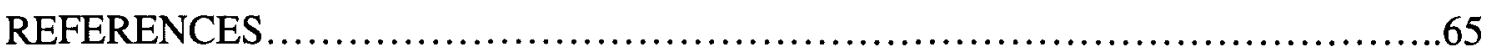




\section{CURRICULUM VITAE.}




\section{CHAPTER I}

\section{INTRODUCTION}

The hip-hop movement provides a platform for marginalized youth cultures to come together at local and national levels to voice silenced experiences. ${ }^{1}$ More recent white-dominated subgenres within the hip-hop movement have utilized rap, a historically black musical genre, as an avenue to share individualized narratives. Non-black rappers respond to the construction of an "authentic" performance in hip-hop by negotiating their racial identity in a variety of ways. Mickey Hess' research on white performers in hiphop music uses the terms "immersion, imitation, and inversion" to describe the ways in which white artists have framed their whiteness in reference to the authentic performance of rap as black (Hess 2005, 373). For instance, Hess attributes the success of hip-hop performer Eminem to the rapper's performance of a new model of white hip-hop authenticity in which "being true to yourself and to your lived experiences can eclipse notions of hip-hop as explicitly black owned" (Hess 2005, 373).

In his analysis of "authentic" white performances in rap music, Hess overlooked the relationship between an ability to "transcend" race to negotiate white authenticity in black music and the history of white theft of black culture in America. Eminem did not succeed in rap music because his "truth telling" narrative and "realness" allowed his audience to overlook his race and thus ignore the history of hip-hop culture. I suggest

\footnotetext{
${ }^{1}$ Although the culture of hip-hop in the broadest sense incorporates break-dancing, graffiti, DJing, as well as rapping, this discussion focuses primarily on rap music. Hip-hop and rap will be used as interchangeable terms
} 
Eminem is successful in rap because he continuously positions himself as a privileged white male in a black genre and also reproduces the stereotypical imagery of gender and class associated with hip-hop.

This project seeks to extend Mickey Hess's approach to white authenticity in two significant ways: amend his strategies for white authenticity to include an interrogation of social location in regards to both racial oppression and privilege, and offer a fourth tactic for white performers to address their whiteness in hip-hop- "conscious subversion".

An interrogation of self and one's own social location in regards to both racial oppression and privilege is necessary for a white rapper to avoid cultural theft and appropriation. Without an awareness of the history race relations in America and its role in hip-hop music, white rappers are in danger of reproducing white consumption and domination ${ }^{2}$. Robert Van Winkle's performance of Vanilla Ice ${ }^{3}$ exemplified an obtrusive ignorance of racial privilege and blatant appropriation of black music that produced his ultimate failure in hip-hop.

A fourth strategy for white authenticity in hip-hop is necessary to encompass white rap performances outside of immersion, imitation, and inversion. The selfidentified "nerd" rap movement, Nerdcore, does not attempt Hess's strategies for white authenticity, nor does the geek identity recreate the gender and race constructions within hip-hop culture. However, Nerdcore performers have negotiated a space in hip-hop where they can offer a "conscious narrative of subversion" for alternative identity performances without parodying or appropriating black music. White, "nerdy" rappers offer a complex

\footnotetext{
${ }^{2}$ In Revealing Whiteness: The Unconscious Habits of Racial Privilege, Shannon Sullivan described the tendency for white folks to act and think as if all spaces are or should be available for them to move in and out of as they wish as the habit of "ontological expansiveness" (10). More on Sullivan in Chapter 5.

${ }^{3}$ More in Chapter 3: History of Hip-hop
} 
performance of identity that showcases an awareness of the dominant constructions of power within whiteness, masculinity, and heteronormativity. This thesis examines how Nerdcore rappers subvert dominant norms and hip-hop stereotypes in regards to race, gender, and sexuality through a performance of nerd "hyperwhiteness". I plan to investigate how white-dominated, self-proclaimed "nerd" rap movement, Nerdcore, asserts white cultural agency within historically black hip-hop music—while the performance of white, nerdy masculinity simultaneously disavows hegemonic power.

A study of countercultural performances of whiteness and masculinity within a predominantly black musical genre is of value for a variety of reasons. First, research devoted to highlighting performances of identity that contradict hegemony showcases the social construction of privilege and power. It is important to locate and encourage performances that destabilize the norms to challenge unequal power structures and offer alternatives to hegemonic identity formations. Confrontation with the invisible allocation of power devoted to dominant categories like whiteness and masculinity is necessary to disrupt and counteract racism, sexism, and homophobia.

Also, white performances of traditionally black music offer a unique social location in which whiteness becomes uncommonly visible. Prior to the subculture of Nerdcore, white rappers have attempted to recreate the hip-hop stereotype of "blackness" through immersion, imitation, and inversion. But, nerd rappers' performance of white identity directly contrasts the stereotypical racial negotiations in hip-hop in a way that challenges even hegemonic notions of whiteness. Hegemonic white identity relies on homogenization and invisibility of whiteness, while nerd rappers emphasize an overt performance of non-normative white identity that forces the viewer to "see" white as a 
racial marking. The conscious subversion of traditional narratives visible in the Nerdcore movement is a new strategy for authenticity in hip-hop and an alternative presentation of identity within dominant culture.

\section{Methodology}

Feminist intervention in popular culture might offer feminist politics a pragmatic strategy to shift the balance of power and prepare the ground for change, and thus help transform society. Since popular culture is a significant site for struggle over meaning, which offers the culture's dominant definitions of women and men, it is therefore crucial to intervene in the mainstream to make feminist meanings a part of everyday common sense. -Suheyla Kirca (Leavy 223)

The exploration of cultural products and texts, like popular music, is important in order to expose how dominant ideologies are created and reproduced. The study of popular music is situated within the field of cultural studies, which addresses the interaction between social meaning and every day practices of life. According to music theorist, Roy Shuker, the study of popular music can illuminate the role of popular culture in "perpetuating dominate values, and the possibilities for subverting and opposing such preferred readings" (Shuker 10). Scholars who concentrate on the texts of popular culture can evaluate and subsequently deconstruct the dominant message within the cultural codes of any given society (Shuker 10). Scholars of communication, Deanna Sellnow and Timothy Sellnow argue lyrics and music work together to offer messages comprised of both conceptual and emotional content (Sellnow and Sellnow 395).

Popular music provides a unique look into the reciprocal relationship between production and consumption of hegemony and thus a glimpse at the social standards within any given era and location. Similarly, countercultural music often offers performances that challenge popular negotiations of identity. An examination of music 
subcultures is a way to show how alternative underground performances of identity are negotiated and thus potentially challenge the "standardization" of dominant norms.

Feminist theory is at the forefront of critically examining cultural artifacts that uphold systemic inequities in modern society. Although, what exactly constitutes "feminist research" is not defined by fixed rules, feminists generally approach research in ways that challenge "how gendered subjectivities are reproduced, by whom they are reproduced, in whose interest they work, and how they are constructed"' (Schroeder 237). Feminist research methods highlight unequal distribution of power and privilege in various forms and are employed to effect "intellectual, social, and political change" (Schroder 237). Theories influenced by feminism have worked to reconfigure normative assumptions and consider performativity ${ }^{4}$ as a strategy to subvert norms. By approaching my study through a feminist lens, I plan to showcase how material and symbolic culture within the Nerdcore hip-hop movement challenges hegemonic performances of race, gender, and sexuality. The nerd performance of whiteness differs from previous negotiations of race in that it doesn't just make the whiteness of the rapper visible, but calls attention to the performative nature of whiteness ${ }^{5}$ in general. My examination of alternative performances of whiteness relies heavily on feminist critique, critical race theory, and whiteness studies. White privilege is the

\footnotetext{
${ }^{4}$ Butler argued that the construction of gender and the establishment of norms of sexual difference are achieved through the continual reiteration and "performance" of discourse. Butler stated, "Gender proves to be performative-that is, constituting the identity it is purported to be. In this sense, gender is always a doing, though not a doing by a subject who might be said to preexist the deed... There is no gender identity behind the expression of gender, gender is performatively constituted by the very 'expression' which are said to be its results" (Butler 24-25).

${ }^{5}$ Utilizing Butler's theories of gender performativity, the performativity of race situates race as a practice that must be maintained in order to identify racialized categories. Thus, similar to Butler's discussion on sex and gender, "the racialized categories of 'black' and 'white' can be seen as normalizing regulatory ideals that generate and form the very bodies that race govern" (Ehlers 335). More on performance of race in chapter two.
} 
unearned advantage of being identified as white in a racially stratified society, and according to Peggy McIntosh, "an invisible package of unearned assets" established through the global hierachization of race (McIntosh 10). Whiteness is a property of social systems that organizes them in such a way that the interests, needs, and values of those racialized as white are normalized, which captures whiteness as an identity, cultural representation, and structured social interaction (Owen 2012). Whiteness operates as an unmarked norm from which all other identities are marked and racialized (Rasmussen, Klinenberg, Nexica, and Wray 10). The invisibility of whiteness and its manifestations allows white privilege to function largely undetected by most white folks. The dominant or hegemonic forms of identity constantly work to appear natural and static, but in practice are fluid and contingent. Male privilege functions similarly, in that hegemonic gender ideology oppresses femininity and non-normative masculinity in order to uphold and reproduce patriarchy, while individual experiences of masculinity are always in flux.

As a researcher, I purposefully pursue research on the "superordinate"6 identities-whiteness, masculinity, and heterosexuality-to challenge the invisible hegemonic power of each. The intersectional ${ }^{7}$ nature of identity categories frames my methodology and approach to analysis; this project does not attempt to individually analyze race, gender, or sexuality, but the interaction among each axes of identity on multiple and simultaneous levels. My work showcases the historical and intersectional processes of gender and race that distribute power and privilege unevenly. This project

\footnotetext{
${ }^{6}$ In "Studying Masculinities as Superordinate Studies", Harry Brod described the necessity for feminists to study the privileged, dominant, and "superordinate" identities to deconstruct systems of power and oppression (Brod 161-175). For more on the relationship between feminism and superordinate studies see Masculinity Studies \& Feminist Theory.

7 "Intersectionality" was first coined by Kimberle Crenshaw (1989) in "Demarginalizing the Intersection of Race and Sex: A Black Feminist Critique of Antidiscrimination Doctrine, Feminist Theory, and Antiracist Politics".
} 
examines alternative performances of superordinate identities that illuminate hegemony and offer space to build resistance and coalitions against hegemonic privilege. It is imperative to examine how systems of oppression interact and reinforce each other to critically challenge racism, sexism, and homophobia.

Chapter two provides a historical look at the social construction of race and how the history has shaped our understanding and experiences of race in America. This outline situates U.S. history within a global context to emphasize the construction of race as a socio-historical international process that has been reproduced and altered over time. My examination of whiteness and performance of whiteness is not meant to recenter white folks in the subject of race, or to analyze "whiteness" in absence of people of color. I am examining the performance of hyperwhiteness in Nerdcore because of its explicit racial visibility in order to problematize unseen white privilege. Race needs to be examined as an organizing framework of oppression and exploitation that traditionally benefits white folks in order to reveal the invisibility, or "mirage of whiteness" (Frankenberg 72). Performativity provides a way of seeing race that foregrounds how whiteness continues to construct itself as a privileged racial category (Warren 2001, 97). The hyperwhite performance of the nerd rapper is situated within a highly racialized and political history of hip-hop. The third chapter examines the history of the hip-hip movement in America and the role of race, gender, and sexuality in rap music. Although, a variety of narratives were available in the early years of hip-hop, the genre transitioned to produce a most "authentic" version of identity that presented a particular image of the culture. The relationship between the values of dominant culture and hiphop counter culture is important to investigate when considering contemporary 
performances of rap music. In order to interrogate contemporary white performers of historically black music, it is crucial to examine the history of white appropriation, parody, and mockery of black culture. Chapter four stresses the "love and theft" ${ }^{\prime 8}$ of black culture by white folks in America and explores the negotiation of power through minstrelsy.

The following chapter on nerd identity and the counterculture of Nerdcore highlights how self-identified nerds have reclaimed a pejorative term to empower those who feel socially ostracized and offer a nerd system of support. In his documentary, Nerdcore For Life, director Dan Lamoureux described the Nerdcore subculture as a "powerful social collision between hip-hop and geek culture." The Nerdcore movement, as depicted in the film documentaries Nerdcore For Life and Nerdcore Rising, provides a public space for self-proclaimed nerds to assert cultural power and agency through hiphop music — even while the performance of white, nerdy masculinity disavows that power. The Nerdcore movement illustrates a transgressive underground mobilization of performative identities that present alternatives to mainstream ideals. Nerdcore's emphasis on the performative nature of both whiteness and masculinity challenges the "naturalness" of such identity categories and showcases the social construction of gender and race.

I argue the Nerdcore movement has thus far avoided white-as-victim rhetoric as well as white appropriation of black culture through a "conscious subversion" of norms. Nerd fans and performers of the movement present a multifaceted awareness of their social location in regards to both privilege and power along lines of race, class, gender, and sexuality. Although nerds are subverting norms in various degrees they are also

\footnotetext{
${ }^{8}$ From Eric Lott's Love and Theft Blackface Minstrelsy and the American Working Class.
} 
aware of the systemic benefits of whiteness; nerds simultaneously benefit from white privilege while challenging the visibility of whiteness through the outlier performance of hyperwhiteness. I conclude that "conscious subversion' is vital to the Nerdcore movement's ability to challenge hegemonic systems of power and privilege.

In the words of Armond White, white performers of rap music "must be able to borrow without losing sight of themselves as borrowers." consciousness of the historical relevance of the movement and an awareness of the marginalized voices rap music typically represent, a white rapper is in danger of producing a "Vanilla Ice imitation"10 and disrespecting an entire cultural movement. A white performance of hip-hop without consciousness of the movement fails to acknowledge the cultural privileges of whiteness and blatantly ignores how whiteness shapes an individual's experience. An acknowledged awareness of racial politics is necessary for a white performer to gain both ethical and cultural success within the movement and challenges the social construction of whiteness.

\footnotetext{
${ }^{9}$ In "Who Wants to see Ten Niggers Play Basketball," Armond White contrasts the performance of white performer Marky Mark with the inauthenticity of Vanilla Ice, arguing that Marky Mark's hip-hop consciousness maintains his own identity without circumscribing an Other.

${ }^{10}$ Hess, Mickey. "Hip-Hop Realness and the White Performer".
} 


\section{CHAPTER II:}

\section{RACE AS A SOCIAL CONSTRUCT}

The construction of race as a category from which to divide and unite humans by phenotype permanently altered the social order of the globe. This chapter aims to outline the social construction of race within a history of colonization and slavery, and the global "racial contract" that emerged. Philosopher Charles W. Mills's use of the "racial contract" defined the formulation of global white supremacy as the political system-"a particular power structure of formal or informal rule, socioeconomic privilege, and norms for the differential distribution of wealth and opportunities, benefits and burdens, rights and duties" (Mills 3). The establishment of race as a framework for human hierarchization created a new human value system that positioned "white" at the top of the social pyramid. Various social, scientific, and moral justifications were utilized to justify the subsequent institutionalization of racial oppression across the globe; racist laws, customs, and norms served to maintain and reproduce the new racial order of the world. The racial contract, as defined by Mills, must be interrogated in order to challenge the contemporary racial hierarchies and manifestations of white privilege.

Many critical race theorists argue that xenophobia and ethnocentricity were the precursors for the development of race. The framework for human hierarchization was motivated by ancient concepts of civilizations and citizen versus outsider distinctions (Winant 2001, 38). Historian, George M. Fredrickson stated that racism originated from a mindset that "regards 'them' as different from 'us' in ways that are permanent and 
unbridgeable" (Fredrickson 9). Fredrickson described this difference as the rationale for using power advantage to oppress or discriminate the "Other" (Fredrickson 9). According to Fredrickson, the social construction of race and "infection of racism" spread alongside colonization in the late medieval and early modern periods (Fredrickson 11).

European colonization and the rise of a capitalist political economy both influenced and perpetuated racial hierarchization. Sociologist Howard Winant defined three major racialized processes that produced ensuing racial categorization: imperalism's creation of modern nation-states, capitalism's construction of an international economy, and the Enlightment's articulation of a unified world culture (Winant 2001, 19). Winant defined modernity itself as a global racial project, claiming that "race was one of the central ingredients in the circular and cumulative causation of modernity" (Winant 2001, 21). According to Winant, European countries made themselves into racially/nationally homogenous entities to challenge their legacies of fragmentation and formed stronger more centralized states (Winant 2001, 22). These nation states were developed through internal unification, the construction of a collective identity, and differentiation/exclusion from "others" (Winant 2001, 23). The ability to easily distinguish outsiders produced early imperialist impulses to convert and control the racial "other".

The "Age of Discovery" established ideal opportunity for global conquest by the dominant European powers upon Africa, Asia, and the Americas. European overseas expansion influenced the rise of a united, privileged, and "white" identity among the colonial empires, juxtaposed against the imposition of a barbaric, savage, and nonwhite identity upon the various indigenous populations. The need for a clear division along 
color lines intensified as the demand for cheap labor increased in the New World and the Native American population no longer sufficed. The native population drastically decreased from the spread of European diseases and wars with the setters. The remaining indigenous populations could not fulfill the demands for cash crop labor. Winthrop Jordan also argued that conquering the Indians was symbolic of the conquest of American difficulties. He stated, "To push back the Indian was to prove the worth of one's own mission, to make straight in the desert a highway for civilization" (Jordan 91). Jordan described the rationale for African slave as "utterly different" and that "Negroes were relatively helpless in the face of European aggressiveness" and demands of colonization (Jordan 91).

The initial export of Africans to the new world for slave labor was a gradual process that laid the groundwork for the massive Trans-Atlantic Slave Trade. Historian, David Brion Davis, described the expanding international market for sugar, molasses, syrup, and rum from the Americas as the prominent reasoning for race-based slavery and the Atlantic Slave System (Davis 105-106). The Trans-Atlantic Slave Trade solidified the hierarchization of the globe by race and set in motion the reproduction of racial classification to justify the new world economy.

European Christians turned to the Bible for religious sources to legitimize the subordination and inhumane treatment of others by race. Religious justification for hierachization was also utilized during the anti-Islamic and anti-Jewish campaigns of the Crusades and the Inquisition and again against the nonwhite "savages" encountered in other areas of the world (Winant 2001 38). The "curse of Ham" rendition of the story of Noah, Ham, and Canaan provided a way for religious followers to remain faithful to the 
biblical account of a common human origin while approving divine authority for the enslavement and subordination of African blacks and their descendents.

A general awareness of the value of racial division was pervasive by the Enlightenment era and science was called upon to further rationalize racism. Even after the abolition of slavery, racialization continued to define the distribution of resources on a global scale and associated a subordinated status with particular phenotypes. The agenda of racial division was no longer focused on conquest and slave labor but instead the nation-building, establishment of national economies, and an assertion of the right of "man" (Omi and Winant 63). Race became a fundamental axis of social organization and according to Winant, "the key organization and ideological component of both state and civil society" (Winant 2004, x).

The significance of racial divisions remained largely unquestioned for the vast majority of the modern era and came to be viewed as "an ineluctable, ineffable component of self and society" (Winant 2004, 153). Races were essentialized as fixed groups, each with distinct behaviors, physical characteristics, culture, and psychology that distinguished one from another. Scientific racism, or the interpretation of data to support presumptions of white supremacy, flourished after the abolition of slavery to rationalize racial hierarchization. The eighteenth and nineteenth centuries witnessed a variety of scholarly research dedicated to the identification and ranking of variations in humankind (Omi and Winant 63). Scientifically "proven racial knowledge" appeared from a variety of disciplines—craniologists, criminologists, evolutionists, psychologists, taxonomists, etc. Race was ultimately defined as a purely biological distinction and the theory of species distinctiveness among humans advocated for the "inequitable allocation 
of political and social rights, while still upholding the doctrine of the "rights of man"" (Omi and Winant 64).

One of the "founding fathers" of American politics, Thomas Jefferson, reiterated such claims in his documents on the development of Virginia. He stated, "Blacks, whether originally a different race, or made distinct by time and circumstances, are inferior to whites" (Omi and Winant 64). In 1853, Count Joseph Arthur de Gobineau published the Essay on the Inequality of Races, a four volume set asserting the belief that superior races produced superior cultures and racial intermixing created the "degradation of the superior racial stock" (Omi and Winant 64). Gobineau's work established the "unintentional justification of all forms of discrimination and exploitation" (Levi-Strauss 5) and laid the foundation for social Darwinism, the Eugenics movement, and Nazism.

The social understanding of race by one of this country's influential figures greatly influenced the foundations of American politics and culture. Based on the 1905 novel, The Clansman, the silent film, The Birth of a Nation emphasized the failure of Reconstruction and the danger of racial integration. Author, Thomas Dixon depicted the Klu Klux Klan as the hero of America in its protection of white women from black men, played by white actors in black face. The film was a major commercial success and the first motion picture to be shown at the White House. The film was selected for its preservation in the National Film Registry by the Library of Congress of its cultural and historical impact on the country.

In the early twentieth century, anthropological research concluded cultural and psychological racial distinctions were not inherited along with physical traits that were taken to indicate racial identity, but instead the result of historical events and 
contingencies (Zack 27). Fran Boas delivered his essay, "The Instability of Human Types" at an academic conference in 1911, which he disputed claims of racial inferiority and in turn presented the cultural differences among people of the world (Boas 101). Sociologist Robert E. Park, philosopher Alain Leroy Locke, and scholar W.E.B. Du Bois were also among the early proponents of race as a social construction as opposed to biological views of race (Omi and Winant 65).

Genetic and evolutionary developments challenged the existence of distinct human races from a biological standpoint (Zack 27). In 1935 Julian S. Huxley and A.C. Haddon published, "We Europeans: A Survey of 'Racial Problems"” to highlight the "pseudo-science" of previous works and presented the new genetic evidence against racial divisions. Huxley and Haddon stated:

'Racial problems' are among the urgent actualities of twentieth century politics. But as soon as we subject the concept underlying them, that of race, to dispassionate analysis, it turns out to be a pseudo-scientific rather a scientific term...Like other pseudo scientific terms, it can then readily be employed to rationalize emotions, and to bolster up the appeals of prejudice, by giving it a meaning to suit the context (Huxley and Haddon 262).

Various documents were published from a variety to disciplines to reiterate the lack of scientific evidence for racial division over the next fifty years. The United Nations Educational, Scientific and Cultural Organization (UNESCO) developed numerous statements in the 1950's and 60's backed by reputable anthropologists and scientists to inform the world of the updated status of the "race problem". The 1952 UNESCO publication of "Race and History" by Claude Levi-Strauss reemphasized the modern scientific approach to race and presented the Declaration of Race and Racial Prejudice in 1978. 
The reconceptualization of race as a social construct was also presented to the general public through a variety of texts. James Baldwin's article, "On Being White... and Other Lies" in 1984 Essence described the construction of a "white" identity as a moral choice by Europeans that shaped the social configuration of colonized nations (Baldwin 91). The 1998 American Anthropological Association Statement on Race was an attempt to release the still "new" facts about race to the public-i.e. politicians, teachers, and scholars—-who were resistant to the idea that race was nonexistent (Zack 89). The AAA Statement stated:

In the US both scholars and the general public have been conditioned to viewing human races as natural and separate divisions within human species as based on visible physical differences. With the vast expansion of scientific knowledge in this century, however, it has become clear that human populations are not unambiguous, clearly demarcated, biologically distinct groups. Evidence from the analysis of genetics (e.g., DNA) indicates that there is a greater variation within racial groups than between them... Throughout history whenever different groups have come into contact, they have interbred. The continued sharing of genetic materials has maintained all of humankind as a single species (Zack 89).

Scholars and activists continued to publically discredit race as a biological fact throughout the following decades because Western societies continue to organize along racial lines.

Resistance to the new conceptualization of race was met from both the broader public and academia because racial hierarchy had become so deeply engrained within cultural hegemony. The ruling groups (white) maintained a popular system of ideas and practices and through the media, education, religion, folk wisdom, etc that sustained their own power (Omi and Winant 67). Nonwhite groups of postcolonial nations continued to exist within a system founded in white supremacy because the modern social order was defined through racial categorization. Winant stated, "only by ordering the social world 
along racial lines, only by assigning racial identities to all beings, only be generalizing a racial culture globally, was the new world order able to constitute itself as a social structure at all" (Winant 2001, 30). The social structure established through the development of imperialism, capitalism, and slavery was fundamental to the economic, social, and cultural order of the modern world.

Marxist philosopher, Antonio Gramsci described the reinforcement of hegemony through simultaneous signification of difference and structured inequalities as maintained on both micro and macro levels. Omi and Winant defined the "common sense of race" as socially learned concepts absorbed without any obvious teaching or conscious inculcation (Omi and Winant 60). The "common sense of race" includes the preconceived notions that are manipulated by the historical value of categorization and subsequent cultural stereotypes associated with racial categories. The ongoing effect of the "common sense of race" upon our individual realities in turn shapes institutions and organizations through which people are imbedded (Omi and Winant 60). Omi and Winant's contemporary definition of race-- the "concept which signifies and symbolizes social conflicts and interests by referring to different types of human bodies"-- shaped their theory of racial formation, or the socio-historical process, by which racial categories are created, inhabited, transformed, and destroyed (Omi and Winant 55).

The "common sense" of race that was established through the racial contract upheld and reproduced systemic "whiteness". Philosopher Terrance MacMullan described whiteness as the widely held belief that a certain group of people, white folks are inherently entitled to greater rights and privileges. This belief shaped unconscious 
"habits of whiteness" that perpetuate the institution of racism, long after the abolition of slavery.

Racial formation theory is often utilized by critical race theorists to reformulate the concept of racism and highlight how the boundaries of race have fluctuated throughout history. World War II and the threat of fascism created a pivotal reinvention and reproduction of the global configuration of race in order to "engage in more inclusive practices" (Winant 2004, 17). Winant argued that the demands of the postwar social order forced racism to adapt to the new social climate. He stated, "thus a new racial politics developed, a reformed variety that was able to concede much to racially based democratic and egalitarian movements, yet that could still maintain a strong continuity with the legacies of imperial rule, conquest, enslavement, and so on" (Winant 2004, xiii

Although the manifestations of racism have transitioned over time, individual and institutional racism have endured through the twenty-first century. Cultural racial meanings still shape the collective "common sense of race" in such a way that visually assumed phenotypes are associated with expectations of particular racial "acts" or performances (Omi and Winant 59). Visible cues become a principle way through which subjects are "individualized, hierarchized, and regulated" (Ehlers 340). According to Robert Warren, "whiteness" is located through a repetition of "mundane and extraordinary" acts that continuously reproduce white privilege, "all while eluding scrutiny and detection" (Warren 92). The labels and markers associated with an identity are socially constructed through the constant performance of those markers, and naturalized through repetition (Warren 95). The reproduction and repetition of privilege establishes cultural and social norms that uphold systemic oppression. 
Anti-racist activist and writer, Tim Wise, described the modern systemic manifestation of racism as a transition from "Racism 1.0 to Racism 2.0 " that allows whites to cling to racist stereotypes while claiming racial transcendence, or a "colorblind" view of society (Wise 15). Eduardo Bonilla-Silva defined colorblind racism as the dominant white racial ideology of the modern era, in which whites refuse to acknowledge the reality of racism and reject any consideration of their own racial privilege under the status of being "colorblind" (Wise 23). The colorblind mentality is blind to systemic injustice and instead blames the individual victims for their own conditions of inequality, and fuels even deeper systemic racism (Wise 19).

The perceptual practice of race categorization and the implication of social meaning become socially obvious when a phenotype does not comfortably fit within the racial dichotomy of white or black, or the "act" of race does not match the perceived race classification. For example, an individual with an unidentifiable race "fails to match the visible markers used by identity discourse to signify race" and according to race philosopher Linda Martin Alcoff, causes social anxiety and confusion for the viewer (Alcoff 68). The anxiety is evident in the typical verbal responses that stem from such circumstances, like "What are you?" or "But you don't look like..." (Alcoff 68). Race is expected to appear and perform in a particular, categorizable fashion to ease the interactions of persons shaped by hegemonic discourse.

Nadine Ehlers extends the work of Judith Butler and Michel Foucault to encompass the performative and disciplinary nature of race. Ehlers described race as a practice, "an ongoing discursive process of racing individuals that must be maintained in order to survive" (Ehlers 334). This classification of racialized bodies serves as a "gate- 
keeping mechanism whereby bodies are separated, assigned racial, meaning and rendered as distinct in their differences" (Ehlers 336). The current dominant conceptualizations of "blackness" and "whiteness" are reliant on the "discursive truths" which have been located in material practices that are repeatedly inscribed and reproduced to maintain meaning (Ehlers 337). Foucault described individuals as participants in the racializing process by conducting themselves "in line with the constraints of regulatory behavioral decrees" (Ehlers 339). Ehlers concluded that the formation and maintenance of race is premised on the individual "being formed by and forming themselves in relation to a normalized identity site and is, thus, always an action" (Ehlers 343).

I argue that nonnormative performances of race, much like Butler's theories of gender, have the potential to subvert hegemonic constructions of white privilege. Calling attention to the performative nature of race, and whiteness in particular, confronts the "naturality" of white as a norm and challenges white privilege as a system. Thomas $\mathrm{K}$. Nakayama and Robert L. Krizek's analysis of whiteness as a strategic rhetoric describes whiteness as lacking "true essence" and defined through opposition of the "other" (Nakayama and Krizek 293). By naming whiteness and showcasing how one performs according to historical understandings of whiteness, Nakayama and Krizek argue that we displace its centrality and reveal its invisible position. Conceptualizing whiteness as a cultural construction, as opposed to a naturally defined category, challenges the innate power relations embedded in this category (Nakayama and Krizek 300).

\section{The Hyperwhite Identity}

A variety of scholars have researched performances of whiteness that are racially marked due to the lack of compliance with socialized boundaries of white-ie. 
"rednecks" and "white trash". White Trash: Race and Class in America by Matt Wray and Annalee Newitz focused on the differences within the general "whiteness" identity, differences marked by categories like white trash, that serve to "undo whiteness as a racial supremacy, helping to produce multiple, indeterminate, and anti-racist forms of white identity" (Wray and Newitz 4). The white trash identity is a visible and marked form of whiteness and thus has the potential to invoke white consciousness and awareness from whites. White trash depicts the intersectional nature of both racialized and classed identities and useful in defining acceptable notions of whiteness. Wray and Newitz described specific visible performances of whiteness as "shifting the gaze from non-whites to whites" in order to focus on the harms of white racism and foster anti-racist forms of white identity (Wray and Newitz 3).

Mary Bucholtz's research on "hyperwhiteness" also addressed white identities that are non-normative, non-hegemonic, and highly marked in the racial economy, but for being "too white" (Bucholtz 2001 85). The hyperwhite identity is marked through the refusal to reproduce the acts of normalized whiteness and instead "construct their identities by cleaving closely to the symbolic resources of extreme whiteness" (Bucholtz 85). One marker of hyperwhiteness performed by the "hyperwhite," or "nerd" community, studied by Bucholtz was the use of "superstandard language" to reject the youth culture norm of coolness. Superstandard English contrasts linguistically with Standard English in its greater use of "super correct" linguistic variables: lexical formality, carefully articulated phonological forms, and prescriptively standard grammar (Bucholtz 88). 
A second marker of hyperwhiteness is visible in the performance, or lack thereof, of sexuality. Ron Eglash described "whiteness" as the perfect sexual balance between undersexuality and oversexuality (Eglash 52). Thus, those who successfully perform hegemonic whiteness enact sexuality between the two extremes. Nerds not only fail to maintain a balance, but are typically associated with utter sexual incompetence. Benjamin Nuggent described nerds as unsocialized and nonintuitive in regards to sexuality and social interaction (Nuggent 2008, 143). Nuggent's analysis of nerd identity described a common inability to read and decipher social cues which produced social awkwardness and lack of acceptance among peers.

Bucholtz's analysis of self-proclaimed nerd culture in a California high school in the San Francisco Bay area positioned hyperwhite nerds as members of a stigmatized social category who were stereotypically casted as intellectual overachievers and social underachievers (Bucholtz 2001, 85). The linguistic, sexual, and social practices of nerds are outside the norm white identity and a presentation of "uncoolness" that is racially marked as "too white" (Bucholtz 2001, 87).

Sociologist Lori Kendall's analysis of nerd identities found that although the imagery of nerds was more prevalent than ever before, the representations continued to reiterate the original negative stereotype (Kendall 2011, 506). Kendall stated, "The popular stereotype of the nerd as the sartorially challenged, anti-social white male hasn't faded from our collective cultural consciousness... ten years ago I thought the nerd stereotype would fade as more people started to use computers in their everyday lives... well that hasn't been true" (Kendall 2009). Images of the nerd identity in film and television increased in the mid 1970's with depictions of intelligent but socially inept 
individuals and the later images incorporated extensive knowledge of computers (Kendall 1999, 262). Kendall argued the negative stereotype of the nerd created a "human portioned off from the rest of humanity, thus guarding against the taint of the potential compromise through close relationship with computers" (Kendall 1999, 263).

The nerd identity, according to Bucholtz, is a purposeful choice that allows those who embrace the identity to reject locally dominant social norms. But, I do not argue that nerds qualify for Bucholtz's claim that nerds are "traitors to whiteness" in their refusal to "exercise the racial privilege upon which white youth cultures are founded" (Bucholtz 2001, 96). Nerds are able to highlight the construction of a homogenized, hegemonic white racial identity through their juxtaposition of nerd hyperwhiteness. Nerds, alongside rednecks, white trash, and other outlier performances of white identity, do still benefit from cultural white supremacy and cannot abstain from white privilege.

I propose that Wray and Newitz's approach to visible performances of white identity can be extended to encompass Bucholtz's theory of hyperwhiteness as an "abject whiteness". Abject performances of whiteness allow the viewer to see the process of performativity - "as race gets made present in the act, one can see the cultural machinery that makes the production possible" (Warren 97). The hyperwhite identity presents differences within whiteness which offers a racial consciousness and anti-racists forms of identity for whites. The hyperwhite identity is incredibly useful to highlight the complex intersections of race, class, gender, and sexuality in modern culture and the social power associated with such identities. 


\section{CHAPTER III:}

\section{HIP-HOP HISTORY}

This chapter seeks to provide a historical outline of the hip-hop movement that highlights the various performances of identity utilized in rap music and the development of a most "authentic" performance defined by a particular racialized, classed, gendered, and sexualized identity. The identity negotiated as "authentic" to hip-hop did not remain static throughout the years, but transitioned "as a reflection of larger social and political currents in society at large" (Ogbar 39). My examination of the past and current performances of race, class, gender, and sexuality associated with the hip-hop movement will provide insight on the construction of identity in broader society, and thus emphasize the potential for counter performances to challenge dominant ideology.

Hip-hop historian, Jeffrey Ogbar cited a variety of social factors that led to the rise of hip-hop in New York City in the 1970's including the Black Power movement, Puerto Rican nationalist activism, and the deindustrialization of large segments of the city that wiped out the economic base of employment for residents (Ogbar 3). Within the documentary Hip-hop: Beyond Beats and Rhymes, hip-hop activist Kevin Powell cited the construction of the Cross Bronx expressway from 1946-1963 as a culprit for the adverse living conditions ${ }^{11}$ of the late twentieth century (Hurt 2005). Kevin Donovan, renamed Afrika Bambaataa formed the Zulu Nation in November 1973 to provide a space for the local youth during the economic decline (Ogbar 3). Block parties with the Zulu

\footnotetext{
"In his biography of urban planner, Robert Moses, journalist Robert Caro argued that Moses intentionally designed the expressway through the South Bronx, even though there were other options in different eras of New York City. See The Power Broker: Robert Moses and the Fall of New York.
} 
Nation and other groups in South Bronx were frequented by graffiti artists and dancers of "a new, nearly gymnastic style of dance" (Ogbar 4). Dancers, also known as "b-boys" and "b-girls," established crews to compete for dominance and popularity at parties (Ogbar 4).

Jamaican immigrant Clive Campbell, also known as DJ Kool Herc, hosted some of the earliest parties associated hip-hop performances (Ogbar 4). Early hip-hop was performed as an entire event, dependent upon a series of artistic activities (Dimitriadis 16). Crews of dancers competed against each other to music technically manipulated by deejays and occasionally accompanied by lyrists ${ }^{12}$. DJ Kool Herc's deejay style isolated the drum beat and transitioned from one beat to the next in a new technique he called "the Merry Go Round" (Chang 79). Grandmaster Flash utilized DJ Kool Herc's tactics but was able to generate his own beats through mastering the techniques of multi-tracking and remixing samples (Chang 79). Many of the musical elements developed and readapted in the Bronx in the 1970s derived from the stylistic characteristics of African and African American culture and became the sounds associated with hip-hop music.

Historian William Eric Perkins linked the influences of the music from the Bronx to oral African cultural traditions and dance (Perkins 2). Perkins described the structure of griot storytelling — chanted rhymes punctuated by the rhythm of the drum — as the foundation for American rap music. ${ }^{13}$ Rap music also incorporated rhyming styles of African traditions of toasts, narrative poems that tell stories in rhyme, and performative

\footnotetext{
${ }^{12}$ Although the culture of hip-hop in the broadest sense incorporates break-dancing, graffiti, DJing, as well as rapping, this discussion focuses primarily on rap music. Hip-hop and rap will be used as interchangeable terms

${ }^{13}$ Rappers have been commonly compared to the storytellers of African culture, "griots." Lommel described griots as serving as both educators and entertainers for the community. "They required and inspired the participation of their people in events and by extension in communities. And, they taunted their enemies, pushed them to fear, and communicated messages of war and resistance" (10-11).
} 
poetry of the civil rights era. Ogbar stated rap music owed much of its style to the African American "badman" ${ }^{14}$ narrative as well as the musical traditions of rock, $\mathrm{R} \& \mathrm{~B}$, and disco (Ogbar 8). Early rap songs typically incorporated call and response routines to entertain and "move" the crowd in small club or house party scenes (Dimitriadis 17). These rap singles were long with little sense of lyrical or musical progression but connected the performer with the audience in closer interactions (Dimitriadis 17).

Rap music established a venue in which the marginalized voices of the community could share their silenced experiences. Although the movement was developed within both African American and Latino urban communities, young African American working-class males emerged as the central representatives (Ogbar 39). ${ }^{15}$ Ogbar described the connection between African American art and hip-hop culture as necessary because it "contextualizes the aesthetic symbols and creative expression found in the early hip-hop community and how they were inextricably tied to the era of the 1970's" (Ogbar 13). The historical relation between rap music and African American culture produced a construction of hip-hop authenticity reflective of the original underground culture of the movement. ${ }^{16}$ Hip-hop historian Imani Perry described hip-hop specifically as "black American music" because it is politically located and derived from

\footnotetext{
${ }^{14}$ Jeffrey Ogbar described the "badman" narrative as the creation of a "fictitious world of conspicuous consumption, status, and prestige" in which the oppressed are powerful and successfully challenge to authority (76).

${ }^{15}$ Ogbar argued that the centrality of Puerto Ricans to the origin of the hip-hop movement is ignored by some for the sake of the "black aesthetic" while others argue that only black men are authentic representations of hip-hop (40).

${ }^{16}$ The terms "authenticity" and "realness" will be used to reflect the same meaning of what it means to be credible in hip-hop culture
} 
African American culture. ${ }^{17}$ Rap music continues to be socially associated with African American culture and history. ${ }^{18}$

\section{Performing Black Masculinity}

Drawing on social constructions of black masculinity, black rappers performed racialized identities that worked to present potential narratives of the community to the public sphere and showcase reality of life for the oppressed. The first wave of rap is described by Hess as the "model for future rap music", commonly characterized as a "pure" moment of creative expression untainted by concerns of getting rich from the music (Hess 2007, 30). Ogbar described the earliest hip-hop performers as mindful of the racist ridicule experienced by their predecessors throughout the twentieth century and therefore recognized the need for more positive, racialized identity within the genre (Ogbar 18).

Black masculinity, as recreated in early rap music, both defied and reasserted the dominant construction of blackness. In Black Looks: Race and Repression, scholar and activist bell hooks analyzed the feminization of the black male body through the patriarchal objectification of the white male gaze and described the black male counter performance as "hypermasculine" (hooks 17). The masculinities performed by early rap artists exemplified the hypermasculine performance hooks described as a contestation of the social hierarchization of race in America. Perry's discussion of masculinity in rap music theorized rap as a location in which new and radical black subjectivities can

\footnotetext{
${ }^{17}$ Imani Perry argued that rap music is constituted as black American music because of four central characteristics: (1) its primary language is African American Vernacular English (AAVE); (2) it has political location in society distinctly ascribed to black people, music, and cultural forms; (3) it is derived from black American oral culture; and (4) it is derived from black American musical traditions (10).

${ }^{18}$ Kembrew McLeod's study of hip-hop magazines, Internet discussion groups focused on hip-hop, press releases sent to hip-hop music critics, and hip-hop song lyrics concluded that hip-hop culture continues to stress the notion that Black cultural expression symbolizes authenticity.
} 
emerge, stating "the black male rapper teases out the contradictions and complexities of his existence in the public conversation that is the music" (Perry 122). In her analysis of hip-hop culture and the public sphere, Gwendolyn Pough discussed the image of black manhood provided by rap music and hip-hop culture as a performance not widely visible since the Black Power movement (Pough 28).The personae adopted by rap artists in this era reflect the historical struggle to construct black masculinity against dominant discourses of whiteness and masculinity. Ogbar stated many black men compensated for their social powerlessness by performing hypermale that often function through female subjugation (Ogbar 76).

As the genre gained more mainstream publicity and earned status outside black urban culture, hip-hop performers negotiated a sense of "realness"- a notion that each artist performs as a unique individual but also maintains a connection to the original culture of hip-hop (Hess 2005, 374). Tricia Rose argued that even when created and consumed by whites, "real" or "authentic" rap music recognizes hip-hop as a black cultural expression that prioritizes black voices from the margins of urban America. ${ }^{19}$

The concept of "authenticity" evolved as a crucial term for the hip-hop movement as rap artists earned more prestige and autonomy. Edward Armstrong identified the three forms of hip-hop authenticity as being true to oneself, claiming "local allegiances and territorial identities" and establishing a connection to hip-hop origins through locale, style, or links to an established artist (Hess 2005, 374). The archetype of "authentic" rap performance shifted within the history of the movement according to the social and political constructions of blackness and masculinity of the era.

\footnotetext{
${ }^{19}$ Rose suggests that rap is a black idiom that prioritizes black culture and that articulates the problems of black urban life but does not deny the pleasure and participation of others $(1994,4)$.
} 
Rap music remained a relatively underground genre until its first commercial hit in 1979, "Rapper's Delight" by the Sugarhill Gang. Part of the initial fascination with the mainstream single was the "novelty of the genre with its emphasis on wordplay and games" (Perkins 11). Lyrical and musical manipulations were integrated into future performances of rap music; the earlier, more simplistic styles were replaced with complex, multilayered sounds and utilized drum machines. In the early 1980 s, electronic sounds were incorporated with rap lyrics and produced what Afrika Bambaataa described as "electro funk"-a fusion of the synthesized beats of disco with the sound system bass of the early Jamaican dance hall (Perkins 12).

The 1980s also marked a transition into mainstream culture for rap music and the hip-hop movement. Run DMC, LL Cool J, and Kool Moe Dee were initiators of what Perkins referred to as the "second wave hip-hop" (Perkins 18-20). Second wave artists transitioned from party lyrics to recording songs and albums; the structure of the song became crucial for radio success. Professor Greg Dimitriadis described the move into second wave hip-hop as a move away from "face-to-face activity to the production and dissemination of self contained narrative texts" as ultimately altering the future construction of hip-hop music (Dimitriadis 22). Dimitriadis stated, "The texts themselves became increasingly structured, the participants less easily identifiable. The dominant paradigm, in which artists transfer messages to audiences, became more important than indexing the quality of the music event" (Dimitriadis 22).

This second wave also intersected with the resurgence of the Black Nationalist movement to construct a socio-political rap performance. The dire conditions of black communities in the late 1980 s shaped by rising unemployment, declining social 
programs, police terror, crime, and a high drug trade fueled the increase of conscious or political rappers ${ }^{20}$ (Ogbar 109). Ogbar described this era as dominated by conscious artists who "laced lyrics with hard-edged black militancy" and often the threat of violence to overturn America's racial hierarchy (Ogbar 22). Public Enemy, BDP, X-Clan, and Brand Nubian exemplified the performance of early conscious rappers (Ogbar 109110).

Black militant rappers were joined by a competing performance of blackness in the second wave of hip-hop, known as the "gangsta" rap genre. Both identities exemplified performative blackness and were dependent on a specific formation of black masculinity. According to professor of Africana Studies Phillip Brian Harper, the most successful performance of an authentic black masculinity is directly related to aspects of street culture and gangsta image. "The masculinism itself," Harper argues, "functions as the seal of proof for any representation of street context that aspires to the conditional of cultural authenticity" (Harper 96). Thus, the "gangsta" image is not just a characteristic of a potential black identity, but rather evidence of the "blackest culture" (Harper 96). Mary Bucholtz's research on performances of masculinity notes how in practice, black masculinities are multiple and diverse, but at the ideological level, the diversity of gender identities is reduced to monolithic forms of masculinity that stand counter to the hegemonic white norm (Bucholtz 1999, 444). Manhood in rap music, accord to Ogbar, is typically defined by three major components: "willful ability to inflict harm on

\footnotetext{
${ }^{20}$ These experiences weren't necessarily part of the biographies of individual rappers, but functioned as a community narrative about the position of young black men in America. For example, Ice Cube's twoparent, middle-class background, and crime-free record, was not evident from his various songs about killing black people and referencing Black women as bitches (Ogbar 63).
} 
adversaries, willful ability to have sex with many women, and access to material resources through crime that are largely inaccessible to others" (Ogbar 75).

Artists like Ice-T, Schoolly D, and KRS-One were some of the earliest rappers to identify with the genre gangsta rap. The lyrics produced with gangsta themes reflected the urban roots of hip-hop and emphasized the violent overtones of the inner-city. Ogbar described gangsta rap as setting an intimidation factor not visible in previous hip-hop music (Ogbar 44). In his 1987 album, Rhyme Pays, Ice T narrated a life on the streets surrounded by violence and crime; the song "Squeeze the Trigger" exemplified early presentations of gangsta rap.

I rap about the life that the city streets gave me Murder, intrigue, somebody must bleed Miami Vice is small time, LA's the big league From the rollin' 60's to the Nickerson "G" Pueblos, grape street, this is what I see The jungle, the 30 's, the V.N.G

Life in the L.A. ain't no cup of ter'. (Ice T 1986)

One of the first major commercial successes from gangsta rap was N.W.A.'s Straight Outta Compton in 1988 with hit title single "Straight Outta Compton" and "Fuck the Police". The lyrics of "Fuck the Police" highlighted the tensions between black urban youth and the police specifically in LA. The violent response proposed lyrically in the song earned NWA national attention and criticism.

Fuck the police

Comin straight from the underground Young ni**a got it bad cuz I'm brown And not the other color so police think They have the authority to kill a minority...

You'd rather see me in the pen Then me and Lorenzo rollin in the Benzo Beat the police outta shape And when I am finished bring the yellow tape 
To tape off the scene of the slaughter

Still can't swallow bread and water. (N.W.A.1988)

N.W.A. frequently incorporated "Do not cross-Police Line" tape in their performances and videos to re-emphasize the negative relationship between African Americans and authority (Dimitriadis 28).

Many Black Nationalist rappers self-identified as "niggas"—an identity affiliated with a community of black men who were "hardcore," or fearless, aggressive men who often expressed themselves in violent ways (Cheney 100). "Nigga" spoke to an identity shaped by class-consciousness, the character of inner-city space, police repression, poverty, and the constant threat of interracial violence. The "nigga" identity linked rappers to a reformed "authentic" black masculinity and the struggle against white dominance. Themes of blackness developed from gangsta rap and the image of the selfproclaimed "nigga" were adopted by rappers and appropriated in future performances as "authentic" representations of hip-hop culture. Ogbar stated "ghettocentric" imagery and "nigga" rhetoric re-shaped hip-hop's blackness so poverty and "hood life" are culturally considered more authentically black than going to college (Ogbar 25).

By mid-1990, the gangsta and "nigga" images had established hegemony in rap, which manipulated the performances of race and class available for commercial rap success (Ogbar 45). Between 1992 and 2006, only two adult solo black male rappers went platinum without "killing 'niggas', referencing bitches, hos, and nihilistic violence" on their albums-Wyclef Jean's Carnival and Will Smith's Big Willie Style (Ogbar 29). Although the image of the street or gangsta rapper was utilized to claim agency for a specific narrative, in many ways this dominant image limited the future performances of gender and race in hip-hop. The financial success of particular performance of black 
masculinity in rap music has inhibited the production of alternative performances in mainstream hip-hop, or space for any identities that challenge the gangsta black rapper image. The oversexed, violent, misogynist identity of "ghetto realness" has become a marker for credibility, as well as a racialized authenticity that conflates poverty, crime, misogyny, and all things ghetto with blackness (Ogbar 30). The multi-platinum success of various gangsta rap artists, like Snoop Doggy Dog, Eazy-E and Dr. Dre encouraged record companies to replicate these images and encourage new artists to perform the gangsta narrative.

As rap gained enormous commercial success, the image of the black male rapper transitioned from a range of black identities to few acceptable and commercially producible images of black masculinity. The second wave of hip-hop brought performances of specific black masculinities to the forefront of rap music; the gangsta and thug identities became personas associated with hip-hop culture as rap further transitioned and mixed with gang culture of inner cities. The record sales indicated a society more eager to embrace ghetto images of black rappers than militant narratives supporting rebellion against social structures (Ogbar 110). The blockbuster success of hip-hop pushed rap music to the Top 40 and in turn produced a new dominant consumer-white folks. By 2002 white consumers made up $64 \%$ of hip-hop music consumption while African Americans made up 31.9\% (Rose 2008, 88). Over the next four years the gap widened even further, with $60.6 \%$ white consumers in 2004 (Rose $2008,88)$. The increase in hip-hop sales from white consumers encouraged major record labels to invest in gangsta music and rappers. 
The face of the production of the music also changed during the shift into mainstream success for rap music. Former president of Def Jam Records, Carmen Ashhurst, described how the larger record companies purchased many of the smaller record companies in the 1980's and "created a formula of conformity to move production" (Hunter 2010). The five major companies that control approximately eighty five percent of recording, production, and distribution in the music industry are AOL Time Warner, Vivendi/Universal, BMG Distribution, Sony Music Entertainment, and EMI Distribution (Kelly 8). Rose problematized this transition in her text, Black Noise: Rap Music and Black Culture in Contemporary America, stating,

What is more important about the shift in hip-hops orientation is not its movement from pre-commodity to commodity but the shift in control over the scope and direction of the profit making process, out of the hands of local Black and Hispanic entrepreneurs and into the hands of larger white-owned business. (Rose 1994, 40)

The history of white colonization and theft of black cultural production has a long complex history in the United States. The next chapter seeks to examine the white appropriation of black culture in America and analyze the potential for "authentic" participation without mimicry or parody. 


\section{CHAPTER IV:}

\section{CULTURAL POLITICS OF PARODY,}

\section{MINSTRELSY, AND AUTHENTICITY}

\section{White Appropriation of Black Culture}

White fascination of black culture throughout American history motivated white appropriation and mimicry of blackness in various cultural productions. Eric Lott described white Americans as historically drawn to emulate and colonize what they cannot be and what society keeps separate—-black culture (Lott 6). In Love and Theft: Blackface Minstrelsy and the American Working Class, Lott described an unconscious desire to control and colonize the panic, anxiety, terror and pleasure evoked by the racial "other" in American society (Lott 6). White "participation" or appropriation of blackness dates back to blackface and minstrelsy of the nineteenth century when white Americans publicly showcased a fascination with and theft of black culture.

Author of Black Like You: Blackface, Whiteface, Insult \& Imitation in American Popular Culture, John Strausbaugh cited the common theatre appearances of the "Yankee", the "frontiersman", and the blackface "minstrel man" ${ }^{, 21}$ in the 1820 's as the first popular uses of blackface in America (Strausbaugh 26-27). The "minstrel man" was typically a white man dressed in blackface who performed routines that ridiculed black humanity (Ogbar 14). Characterized by "buffoonish style" of singing, dancing, and

\footnotetext{
${ }^{21}$ Strausbaugh also added the Outlaw/Gangster, the Preacher, and the Celebrity to the list of popular images in upcoming media tools (28).
} 
speaking, minstrelsy depicted "black people as infantile and pathological while underscoring the importance of race to the meaning of democracy in America" (Ogbar 13). The performance of the black minstrel, or "coon", presented what was assumed "authentic blackness" by white Americans and thus affirmed the notion that black folks were "unfit for the responsibilities of democracy" (Ogbar 13). Whites often justified this blatant racism through the notion that blacks were slaves for so long that they were mentally incapable of rational decision making and therefore should be denied the right to vote to prevent the nation's demise (Strausbaugh 91). Additionally, the happy go lucky performance of the coon character affirmed to whites that blacks were happy with their status of citizenship and quality of life.

Strausbaugh described this era in the United States as experiencing a pivotal ideological shift from democracy to collectivism through the construction of a recognizable American culture (Strausbaugh 28). The extension of suffrage to all white men in the Jacksonian era of the 1830's helped form a united white identity across class and the minstrel imagery emphasized the racial dichotomy. Ogbar described the negative depictions of black people in minstrelsy as promoting an "alliance between northern white workers and southern planters by affirming a universal commitment to white supremacy and its corollary black subjugation" (Ogbar 13-14). The rise of American popular culture reinforced racial divisions and in turn disintegrated working class solidarity among poor whites and blacks.

The transition from blackface to a full minstrel show began in 1842 when performers Edwin P. Christy and Daniel Decatur Emmet expanded the form from a solo act to a four piece band (Strausbaugh 102). Celebrity singers, dancers, and comedians 
were added to the growing shows along with extensive sets and costumes. The reoccurring characters were typically cultural stereotypes and stock images of blackness in America, including country coons, "plantation darkies", babbling preachers, etc. (Strausbaugh 108). Similar to traveling circuses, the minstrel troupe often began the performance with a parade of all the characters from the train station to the venue to illicit interest in the show (Strausbaugh 104).

This new version of minstrel plays performed as standalone acts of song and dance caught on quickly across the nation. According to Ogbar, the 1843 performance of the Dan Emmett's Virginia Minstrels at the Chatham Theatre in New York City marked the institutionalization of minstrelsy and the immense national commercial appeal of blackface (Ogbar 13). After their success in New York, the Virginia Minstrels toured England and Ireland and similar minstrel acts appeared all across the U.S. (Strausbaugh 105). Although the various minstrel productions in America presented a range of social issues, most often the shows reproduced racist propaganda. ${ }^{22}$ A specific example Strausbaugh highlighted of such propaganda was the song "Root, Hog or Die" popularized in the mid 1850's through minstrel shows:

I'm chief cook and bottlewasher, capn' ob de waiters;

I stand upon my head

When I peel de Apple dumplins.

I'se happiest darkee on de top ob de earth I get fat as possum in de time ob de earth Like a pig in tate patch dar let me be Way down in old Virginny whar its Root, hog, or die... (108-109)

Ogbar described how racist performances like ones cited by Strausbaugh functioned on two levels-the first as a construction of the American identity as inherently white

\footnotetext{
${ }^{22}$ John Strausbaugh offered specific performances that showcased abolitionist agenda and greed of upper classes (111-118).
} 
through the juxtaposition of the minstrel performances. The carefree, irresponsible coon character produced a distinct contrast against the articulation of national white identity (Ogbar 14). The minstrel shows not only provided easy entertainment but also simultaneously justified the sociopolitical and economic structure of the U.S. in its rationalization of white supremacy (Ogbar 14). According to Strausbaugh, the only experiences of "black" many white Americans witnessed in the mid nineteenth century were the blackface performances in the minstrel shows (Strausbaugh 108). Over ninety percent of black Americans were enslaved in the early $19^{\text {th }}$ century and even free blacks were generally barred from public theatres, thus the minstrel show was a space designed for white consumption of reproduced "black" culture (Ogbar 14). The dominance of blackface and minstrel performances in American popular culture faded and resurfaced throughout the following decades. Vaudeville, or a type of stationary sideshow, grew out of the same demand as minstrel shows and gained popularity in the United States. Cartoons, silent movies, popular novels, advertisements, and music were all arenas for the reproduction of minstrelsy (Ogbar 16). White consumption of black culture intensified once again in the 1920's, when "authentic" black music, dance, and nightlife rose in popularity (Strausbaugh 143). The participation of historically black music and dance was a way for American youth to rebel against white standards of morality. Kevin Phinney described whites "slumming" in Harlem in the 1920's as a "chance to dip a toe in the salacious Negro world coupled with the abstract threat of near-death" and equally "irresistible and exhilarating" (Phinney 106). Clubs that permitted interracial dancing and mingling surfaced in Harlem and created a strong backlash by the surrounding white communities (Phinney 106). 
The early twentieth century witnessed the birth of various music forms from African American culture, including blues, jazz, and swing, which were in turn consumed, adapted, and exploited by whites (Phinney 106). Phinney highlighted how the mainstream success of any black music genre in turn produced the commodification and reproduction by whites, who typically reaped more economic benefits and fame (Phinney 105). For example, the cultural association of Elvis with the birth of rock'n' roll in many ways erases the black roots of the genre. Tim Moore, the Communication Director for the Rock and Roll Hall of Fame and Museum, stated, "the music of the Black Church and the music of blues are the bedrock of what became known as rock'n'roll in the early 1950's... the contribution of black artists cannot be overstated" (Chappell 1997). An understanding of the history of white colonization and domination of black culture in the U.S. is necessary to comprehend the appropriation of black music. White performers of historically black genres have negotiated their identities in particular ways to either present credibility or mimic blackness to achieve popular success. White performers, particularly in hip-hop music, have struggled to find their place in a genre so defined by "authentic blackness", and attempted to overcome their "outsider" status in various ways.

\section{White Rappers "Keepin it Real"... or not}

The debut and success of the Beastie Boys in 1986 marked a pivotal transition in hip-hop history - the visibility of white performers in a predominately African American performance culture. The commercialization of rap music in second wave hip-hop extended the audience for the music into predominately white areas and increased the 
white fan base for rap. Some critics of white consumption and involvement in hip-hop describe hip-hop as "a modern minstrel show". ${ }^{23}$ White rappers in mainstream hip-hop negotiate their race and masculinity in different ways to achieve success and credibility within a musical genre so defined by the performance of "authentic" black masculinity.

The tactics of white authenticity in rap music as described by Hess are visible in three distinct eras of white performances of hip-hop: Pre-Vanilla Ice 1973-1990, Vanilla Ice 1990-1999, and Eminem 1999-Present. ${ }^{24}$ The Pre-Vanilla Ice era is noted for the performances by The Beastie Boys and Marky Mark, whose successes are commonly attributed to their authentic representation of the roots of the movement and each group's ability to keep it "real." The Beastie Boys's collaborations with Run DMC and Public Enemy further legitimized their image and performance as white rappers. Ogbar described the Beastie Boys's relationship with rap music as "more like zany friends than cultural bandit interlopers" (Ogbar 56). Although the group never directly confronted their whiteness lyrically, they did speak out against racism on the songs "B-Boy Bouillabaisse" and "Lookin Down the Barrel of a Gun" (Hess 2007, 117). Marky Mark earned credibility through the construction of an ethnic Irish-American marginalization, rather than a white racial identity. His hip-hop authenticity was established through the reference of his Irish heritage and his criminal involvement as a teenager in Boston (Hess 2005, 380). Both groups immersed themselves in the culture of the music and assimilated with acceptable images of masculinity within the genre-i.e. the gangsta or the rebellious teenager.

\footnotetext{
${ }^{23}$ For more discussion on hip-hop as a modern minstrel show see Bakari Kitwana, 101-105

${ }^{24}$ Hess commonly used this era distinction within his research of white performers in hip-hop music. The Eminem era outlined as 1999-"present" would include up to the year 2007.
} 
The failure of Vanilla Ice's imitation of black culture and his mimicry of the gangsta narrative served as a warning to future white rappers. Robert Van Winkle, or Vanilla Ice, attempted to fabricate a personal history of violence and criminal activity to imitate an experience associated with rap music. Ken Parish Perkins published a story that presented Vanilla Ice's true history-- a young man from the Dallas suburbs from a wealthy, crime-free upbringing (Hess 2007, 113). SBK Records defended Vanilla Ice with the statement, "it may not be true that he grew up in the ghetto-but maybe he spent a lot of time there" (Hess 2007, 114). Critics of his music accused Vanilla Ice of collaboration with the white-controlled music establishment and "ripping off" black music for profit (Powell 253). His ultimate failure at realness and authenticity ruined his chances as a successful rapper in the hip-hop world and established further limitations and boundaries for future white rappers.

Hess's timeline of whiteness in rap defines the "Eminem Era" in 1999 as a reestablishment of credibility after Vanilla Ice's failures. The Billboard's Hot 100 chart did not include any new white artists until Eminem's debut in 1999 (Hess 2007 124). Marshall Mathers III, better known as Eminem, focused lyrically on his own racial identity and openly discussed how his status as a white male affected his performance as a rapper. According to Hess, Eminem's "realness" and honesty about his identity, biography, and social position facilitated his mainstream success and presented a new model of white hip-hop authenticity in which "being true to yourself and to your lived experiences can eclipse notions of hip-hop as explicitly black owned" (Hess 2005, 373).

Eminem's lower class upbringing was crucial to his "authentication" in hip-hop; his lyrics reflect his actual biography in a poor, urban social location (Hess 2007, 124). 
He also repeatedly referenced Vanilla Ice's epic failure in hip-hop in contrast to his "real" narrative of adversity. Similar to successful white rappers before him, Eminem was also legitimized through his association and connection with rapping legend, Dr. Dre (Hess 2007, 125). His first album The Slim Shady LP (1999) sold over four million copies, The Marshall Mathers LP (2000) and The Eminem Show (2002) each sold eight million copies; the success from each of his first three albums made Eminem the first artist to win the Best Rap Album Grammy for three consecutive albums (Hess 2007, 128).

Although Hess's analysis is well illustrated and supported, it fails to recognize how and to what degree successful white rappers assimilate to stereotypical imagery of a particular performance of black masculinity tied to hip-hop and how this affects their success as artists. Eminem is infamous for his violent, homophobic, and misogynistic lyrics which mirror the hypermasculine standards of contemporary commercial hip-hop. Eminem's track "97 Bonnie and Clyde" from The Slim Shady LP generated immense controversy over lyrics narrating his wife's murder in front of his child:

Baby, don't cry honey, don't get the wrong idea Mamas too sleepy to hear your screamin in her ear That's why you can't get her to wake, but don't worry Dada made a nice bed for mommy at the bottom of the lake Here, you wanna help dada tie a rope around this rock?

We'll tie it to her footsie then roll her off the dock. (Eminem 1999)

Eminem's use of violence and misogyny is a performance of the gangsta narrative in hiphop; his lyrics successfully replicate the stereotypical imagery of blackness in America. Gender theorist, Liam Grealy, described Eminem as a cultural hybrid, "utilizing mimicry to establish a marginal identity based on his class position and (white) skin color" (Grealy 860). 
The subjugation and objectification of women are also central themes of

Eminem's lyrical content. His wife and mother appear as frequent victims throughout each of his albums, but the single "Stay Wide Awake" from his 2009 album, Relapse, featured his desire to brutally assault unknown women.

Fe Fi Fo Fum

I think I smell the scent of a placenta

I enter Central Park, its dark, it's winter in December

I see my target with my car, and park and approach her tender

Young girl by the name of Brenda and I pretend to befriend her

Sit down beside her like a spider, hi there girl you mighta

Heard of me before, see whore you're the kinda girl that I'da

Assault and rape and figure why not try to make your pussy wider

$\mathrm{F}^{* * *}$ you with an umbrella then open it up while that shits inside ya. (Eminem

2009)

Anti-sexist filmmaker and activist, Jackson Katz, noted the "guilty pleasure" man of

Eminem's fans experience in identifying with aggressor from the lyrics (Katz 2002).

Even though Eminem often defends his lyrics as "just a song", Katz argued that "rapping and joking about sex crimes has the effect of desensitizing people to the real pain and trauma suffered by victims and their loved ones... one of the most damaging aspects of Eminem's violent misogyny and homophobia is how normal and matter of fact this violence comes to seem" (Katz 2002).

Hess's research also ignores the level of social consciousness necessary for a white rapper to analyze his or her own experience of whiteness to distinguish his or her own white privilege. I argue that Hess's definition of a new white authenticity is available for white rappers, like Eminem, who recognize both their privileges and their hardships as white performers of hip-hop. My analysis seeks to extend Hess's interpretation of whiteness in hip-hop to include current, socially conscious, underground 
performances by white rappers who attempt to establish a performance of masculinity and race not traditionally accepted within hip-hop or even the dominant discourse. 


\section{CHAPTER V:}

\section{REVENGE OF THE NERDS}

"I didn't know what I wanted to rap about so I was just pretending to be everything I saw on TV. It wasn't real and I wanted it to be real. So, I started rapping about nerdy stuff:about being white-skinned and about being in love with my best friend's sister... I rap about technology, comic books, unacquainted love, all kinds of your geeky stuff that isn't covered in mainstream hip-hop. Because it relates to me, and it relates to the people who listen to my music, as opposed to the stuff you hear on the radio. I don't know anything about being in love with a stripper." -Beefy, Nerdcore For Life

Born on the Internet, Nerdcore hip-hop is rap music made by geeks for geeks and covers traditionally "nerdy" topics such as comic books, video games, science fiction, anime, and technology. Damien Hess, also known as MC Frontalot, originally coined the term "nerdcore" to describe his "spinning of geek shame into bravado through rapping" and is commonly referred to as the "the Godfather of Nerdcore Hip-Hop" (Nerdcore Rising). MC Frontalot began publicly rapping about his "geeky" identity and failure to abide by both mainstream concepts and hip-hop's expectations of masculinity in $2000 .^{25}$ Remixed Magazine described Hess as "balding, soft-spoken guy in his late midthirties...twitches and writhes like a white boy and doesn't make eye contact with his audience much, but once on stage he is a ball of geek fury, spitting out sharply observed machine gun lyrics" (Remixed Magazine 2012).

Though it has existed online for more than a decade, only recently has Nerdcore gone from being an Internet fad to an underground cultural phenomenon. In his discussion of the Nerdcore culture, Jason Tanz described the music as "very true to hip-

\footnotetext{
${ }^{25}$ For more history on MC Frontalot see Nerdcore Rising, Dir. Negin Farsad and Kim Gatewood. (2008)
} 
hop's roots, because we're talking about day-to-day life. It's just day-to-day life for a kid who's living in the suburbs and spending two to eight hours every day on the Internet" (Tanz 157). Nerdcore and mainstream hip-hop artists each utilize rap music as an arena to perform their unique alternatives to traditional hegemonic expectations of gender and race, although each negotiation of alternative identities plays out in unique ways.

The content of Nerdcore differentiates itself from mainstream hip-hop by speaking to the heart of "geek" culture, but utilizes hip-hop's ability to express the oppressed experiences of today's youth. The Nerdcore movement developed as a counterculture space in which nontraditional audiences of rap music could claim ownership of identities alternative to both dominant ideologies and hip-hop's constructions of gender and race. Nerdcore challenges the traditional misogynistic, hypermasculine mainstream construction associated with both white and black masculinities and offers a safe space in which to present alternative gender performances. Nerdcore masculinity embraces the "unsuccessful" performances of masculinity typically associated with "geek" identitylack of athleticism, social ineptitude, unassertiveness, lack of sexual endeavors, emotional demeanor, etc.

\section{Nerd Culture's Challenges to Hegemonic Identity}

The term "nerd" first appeared in Dr. Suess's If I Ran a Zoo, alongside a long list of fantastic creatures, "I'll sail to Ka-troo and bring back a it-ktuch, a preep, a proo, a nerkle, a nerd, and a seersucker too" (Anderegg 25). Newsweek released the first public contempory use of "nerd" in 1951 as synonymous with "drip" or "square" to emphasize an individual's negative social standing among peers (Anderegg 36). Professor of psychology and child psychotherapist, Dr. David Anderegg, credited the show Happy 
Days with the cultural implantation of the term "nerd" in 1974; the character "the Fonz" frequently referenced "nerds" as the ultimate social outcasts, which influenced the widespread use in popular culture (Anderegg 36).

In his book entitled, Nerds: How Dorks, Dweebs, Techies, and Trekkies Can Save America, Dr. Anderegg described how young children may not fully understand the meaning behind the term of "nerd" or "geek" ${ }^{26}$, but they do comprehend that nerds are devalued people and are "kids who were weird, different, and inadequate" (Anderegg 106-107). From his experience with identity formation and children, Anderegg comprised a list of qualities often associated with "nerdom":

Nerds are kids who are too goody-goody, like Boy Scouts, but they are also weird and sick, like kids with Asperger syndrome who murder their classmates. Nerds are kids who are close to their parents and who are protected and cared for by adults but who don't wash or use deodorant and have no idea how they are supposed to look... Nerds are too interested in details and arcane knowledge; they are too interested in facts. They are too literal and scientific, except when they are too interested in fantasy or magic or alternative realities. It's no wonder kids are confused. (Anderegg 234)

Anderegg's experience reflected the wide variety of commonly activities associated with various aspects of nerd identity; qualities ranging from physical appearance to personal demeanor, frequency of computer use, interest in math and science. The nerd identity is far from stable and reflects the cultural norms of "cool" or trendy within a specific location and era. Anderegg concluded that for young children nerd is everything that the good, "cool" kids are not, until specific qualities are identified as "nerdy" in later years. He outlined five "foundations of nerdiness" that typically categorizes an adolescent as a

\footnotetext{
${ }^{26}$ In some contexts, "nerd" and "geek" are defined as mutually exclusive identities, while other times they are synonymous. Dr. Andergg described a "geek" to be a person who obsesses in one area or another and a "nerd" as a "highly intelligent person who is very scholarly and does well in many domains such as math, science, computing, etc" (33). For the purpose of this project, I will use "nerd" and "geek" interchangeably to represent the identity that merges the two.
} 
nerd by middle school: lack of sexual appeal from others, interest in technology, lack of interest in their personal appearance, enthusiasm for subjects deemed "boring" by peers, and persecution by nonnerds (Anderegg 23). Within a hypersexualized culture, young teens quickly learn that the kids that who succeed at science and math are viewed as "creepy and unsexy" and should be avoided to prevent social suicide (Anderegg 67).

Anderegg argued that the social dichotomy between nerd and nonnerd is rooted in the "man of action verses the man of reflection" rhetoric utilized throughout American history (Anderegg 92). "The American Scholar” speech by Ralph Waldo Emerson to Harvard graduates in 1837 differentiated American scholars from other intellectuals in their priority to act instead of reflect without purpose (Anderegg 86). Emerson compared "speculative men" with women in their tendency to waste time with books and thought without action (Anderegg 87). Anderegg cited this speech in particular because of the framework it relied upon and solidified for the successful modes of manhood in America and the appropriate performance of intellect for scholars. Emerson's descriptions of the reflective intellectual men founded the roots of the feminization of male intellectuals, or nerds, in contemporary society.

The geek identity has been defined in opposition to historical performances of hegemonic masculinity. Although, what constitutes a successful performance of hegemonic masculinity has evolved over time, the general model of masculinity in America has remained relatively constant for the past few decades. In his historical analysis of manhood in America, Michael Kimmel cited Erving Goffman in his description of the static model for masculinity. "In an important sense," Goffman stated, "there is only one complete unblushing male in America: a young, married, white, 
northern, heterosexual, Protestant, father, college educated, fully employed... any male who fails to qualify in any one of these ways is likely to view himself-during moments at least—as unworthy, incomplete, and inferior" (Kimmel 2006, 4). Kimmel discussed the construction of American black masculinity as a continuous effort to reassert the power lost from hegemony through the use of "homophobic slurs and full throttle phallic posturing" (Kimmel 2006, 232).

Laurence Steinberg, Bradford Brown, and Sanford Dornbusch's 1996 study of school behavior found that nerd classification and academic success were often justification for peer to peer teasing. They described the children labeled "brains" or "nerds" were the "least happy with who they are-nearly half wished they were in a different crowd" (Steinberg, Brown, and Dornbusch 145). In Bishop, Bishop, Gelbwasser, Green, Zuckerman, Schwartz and Labaree's 2003 study of student culture and norms, the authors compared nerd status to "having a communicable disease" (Bishop, Bishop, Gelbwasser, Green, Zuckerman, Schwartz, and Labaree 143). The article stated, "Everyone tries to avoid a nerd because hanging out with one sends a signal that person is a nerd as well. Thus, those who have an outcast label placed on them find it hard to make new friends and often lose old friends" (Bishop, Bishop, Gelbwasser, Green, Zuckerman, Schwartz, and Labaree 143). Their study also found a positive correlation between student grade point average and harassment experienced in the classroom (Bishop, Bishop, Gelbwasser, Green, Zuckerman, Schwartz, and Labaree 175). Other forms of peer teasing occurred within the groups studied, but the groups identified as "nerds" were constantly bullied for their counter hegemonic interests and presentations of identity. 
Even though the geek identity presents a performance of masculinity that is outside Goffman's model of hegemonic masculinity, this comparison is not an attempt to construct a narrative of sameness or an indication that both marginalized groups-white geeks and black rappers-experience similar oppressions. I am working to showcase the ways in which both African Americans and geeks have utilized rap music as a genre in which to negotiate their "othered" experiences in contrast to normative constructions of identity. The Nerdcore movement works to reclaim the label "nerd" or "geek" as a positive identity markers to empower a typically marginalized group.

Bucholtz's analysis of self-proclaimed nerd culture within a California high school positioned nerds as hyperwhite by "distancing them from the African American underpinnings of European American youth culture" (Bucholtz, 2001, 86). One marker of hyperwhiteness performed by the nerd community studied by Bucholtz was the use of "superstandard language" to reject the youth culture norm of coolness. Bucholtz's research highlights nerd identity as an example of a white identity that is "nonnormative, nonhegemonic, and highly marked in the local racial economy" (Bucholtz 2001, 85). The nerd identity is racially marked because self-proclaimed nerds refuse to engage in culturally acceptable practices of unmarked whiteness and instead construct an identity of extreme whiteness. The nerd's performance of hyperwhiteness disrupts the invisible markers of whiteness and undermines the racial project of whiteness as a normative and unmarked construct. The nerd identity according to Bucholtz is a purposeful choice that allows those who embrace the identity to reject locally dominant social norms. Benjamin Nuggent, author of American Nerd, described nerds as "not simply victims of the 
prevailing social codes about what's appropriate and what's cool; they actively shape their own identities and put those codes into question" (Nugent 2007).

Lori Kendall's analysis of American nerd culture concluded that recent popular images of references of nerds may provide ironic reconfiguration of nerd identity they still ultimately fail to challenge the negative tone associated with the stereotype (Kendall $2011,506)$. As computer use grows and computer professions like programming increase in monetary and cultural value, it would be logical to assume the "nerd" identity associated with expert knowledge in technology would gain cultural agency as well, but according to Kendall the nerds can't seem to escape a marginalized and undesirable identity (Kendall 2011, 506)

\section{Nerd Identities in Nerdcore}

The Nerdcore Movement has embraced all nerd presentations of identity, including the technological obsessions and anime fandom. Multiple Nerdcore artists including MC Frontalot, Ultraklystron, Nursehella, The Sucklord, and The Lords of the Rhymes are known for particularly "geeky" costumes that further accentuate each of their nerd identities. MC Frontalot's stage attire presents a stereotypical nerd appearance--a short-sleeve button-down shirt, a mismatched and colorful tie, and a pocket protector. Nursehella and Ultraklystron commonly perform in anime-themed or gaming attire, while The Lords of the Rhymes dress in hobbit costumes to correlate with their Tolkien-themed lyrics. These costumes further distance Nerdcore rappers from the appearance and presentation of normative masculinity and of hip-hop.

The locations in which Nerdcore is performed, advertised and created also distance the genre from mainstream hip-hop. Nerdcore music is mostly made with 
computer software and dispensed online for free or minimal cost. RhymeTorrents.org, Nerdcorenow.com, Hipsterplease.com, and Nerdcorehiphop.com are forums that organize and compile Nerdcore raps for mass consumption; Boingboing.net and Slashdot.org provide "nerd news" and recommend upcoming nerd artists to the nerd community. Live Nerdcore performances are available at gaming conventions like Penny Arcade Expo, at nerd-centered arenas like Nerdapalooza, as well as some small-scale tours. In his article entitled, "Geek Pride Blooms Into a Real World Sub-Culture Washington Post staff writer, Anthony Faiola, described the establishment of Nerdcore subculture as a transformation of alienated individuals into a "virtual thriving community, whose members are physically interacting as never before at concerts, comedy clubs, and 'nerd expos"” (Faiola 2007).

The images and lyrics of mainstream hip-hop have relied on presentations of hypermasculinity through the repression of femininity and homosexuality to access privilege and power. MC Frontalot developed an entire musical subculture in which performers could discuss and present alternative and nontraditional ideals of race, gender, and sexuality. Music critic, Josh Gross, described MC Frontalots's lyrics as commentary on both the oppressive structures of hip-hop and dominant society. Gross claimed:

Rap often manifests itself as an ego-fueled celebration of violence, both physical and emotional. It can make hip-hop unapproachable for people to dig the beat but not the beatings. MC Frontalot flips that on its head...From a philosophical stance, this approach might seem shallow-an erosion of the gravitas that is hiphop-however the commentary of Frontalot's lyrics is anything but. His rhymes give a credible voice to a subculture, exactly as traditional hip-hop does. Frontalot is a soldier for all things Zelda and is self aware enough to place that into a larger context (Gross 2011).

In the documentary Nerdcore Rising, MC Frontalot described writing raps as a teenager about his failure to abide by cultural norms and lack of acceptance by his peers. 
Frontalot's lyrics commonly referenced both his inability and his lack of interest in the pursuit of the opposite sex and sexual conquest, taboo topics for hegemonic masculinity. As opposed the sexualization and subjugation of women in dominant hip-hop lyrics, MC Frontalot described an interest in spending "quality" time with his partner while fully clothed.

Why don't we just treasure it, cuddle and rub noses, put clothes on and on and don't stop till we're totally clad. Then my soul could be glad, to have a moment in your company without all the moans, maybe replenish some ATP, settle our bones.

Dulcet tones: share feelings, ideas, and views.

How come you want me for my body when my brain is so huge? (MC Frontalot "Just Once")

These lyrics outlined Frontalot's desire for an emotional connection with his potential significant other, a performance in direct opposition from the cultural expectations of masculinity. Hegemonic ideals of masculinity emphasize physical and sexual domination of women and ostracize emotional connections with peers. Damien Hess stated, "If you don't fit into the traditional aspirations of masculinity, especially if you are a teenager, if you aren't actively struggling to attain those goals of masculinity, then you get chastised by the word fag" (Nerdcore Rising). The label of "gay" or "fag" for a young man by his peers has become a way for younger men to instill hegemonic masculinity and suppress alternative gender performances.

Kimmel attributed the more prevalent threat of homosexuality among young men in recent history to an attempt to restrict gender nonconformity (Kimmel 2009, 76). These young males' anti-gay sentiments have become efforts at gender policing; one survey found most American boys would rather be punched in the face than labeled gay by their peers (Kimmel 2009, 77). Being labeled "gay" has come to mean failing at 
hegemonic masculinity for many young American men. MC Frontalot has not only acknowledged the potential for non-heteronormative performances of masculinity within geek culture, but has also released a song entitled "I Heart Fags" describing his respect for the queer community:

I love fags because I am a San Franciscan if you're dissing on my homos then this censure's what you're risking (I'm insisting on containing my temper but listen up): you shouldn't ought to be intolerant about who queers like to fuck!

MC Frontalot and the Nerdcore movement have developed a hip-hop space that not only refrains from judgment of a queer identity, but also celebrates performances of sexuality and/or gender outside mainstream regulations.

The construction of the nerd identity within a rap performance contradicts the typical presentation of a hip-hop masculinity. The nerd artist performing within a genre so often defined by its hypermasculinity, violence, and criminal activity not only offers a new and transgressive masculinity, but also challenges the performance of stereotypical masculinity within hip-hop. Nerdcore rap emphasizes the inability of the nerd rapper to relate to and perform hypermasculinity. In his song entitled, "Crime Spree," MC Frontalot makes a spectacle of his lack of "toughness" and criminal activity as a rapper.

Riding all around on my bike with no helmet. Commit mail fraud whenever I see a mailman. Got a jaywalking ticket. I crumpled it up!

Still bump the bootleg cause I'm hanging tough [we're ruff!].

Crime spree that I'm on,

Breaking the law until the break of the dawn,

Then I'll break it again, then I'll break it some more.

(MC Frontalot, you're so hardcore)

Rap artists who successfully negotiate identities and performances at odds with mainstream constructions of hip-hop masculinity can challenge the presumed correlation 
between rap artists and the stereotypical gangsta image. MC Chris' lyrics in the song entitled "Evergreen" discuss a similar narrative and struggle from white suburbia to relate to the hypermasculine and criminal stereotype within mainstream hip-hop. The song tells the story of a group of white adolescent males breaking into a Christmas tree lot, drinking underage, and being asked to leave nicely by the police. MC Chris describes the experiences of the teenage boys as "suburban gangstas," as opposed to the "real" gangstas depicted in mainstream and commercial rap songs.

Supporters of Nerdcore hip-hop have responded favorably to the reclamation of nerd identity through rap music. Lamoureux's interview with Nerdcore performer, Monty showcases the power asserted through performing and offering alternative identities to the public. "People are self-identifying as nerds and it used to be this horrible thing and now we are reclaiming the term, it's kinda like the gay community reclaimed the term 'queer'... we are saying, yea I'm a nerd and we are proud of that" (Nerdcore For Life). Nerdcore artists utilize rap music as a platform to assert cultural agency and claim ownership of an identity in opposition to both mainstream and hip-hop ideals.

The fans of the music have blogged, posted, and published an array of reviews depicting their relationship to the movement. Nerdcore forum participant "Xuntra" described the community as an attempt to "empower the weak... to make it so nerds can be nerds without feeling inadequate or like a 'loser' all the time" (Xuntra 2009).

Nerdcore blogger "Lukifer" echoed a similar response to the community:

Most of us experienced a culture where if you were too different, too intelligent, too independent from social convention, you would be ostracized, if not outright persecuted... I realize I tread on thin ice by comparing geek culture persecution to the oppression of gays or other minorities, but while it doesn't compare in scale, that doesn't mean it's insignificant. Whether persecution is subtle and mild or cruel and inhuman, a second class citizen is still a second class citizen. Nerdcore 
is about taking what was once a pejorative term and owning it, turning a source of shame into a source of pride (Lukifer 2009).

The online connections developed through a virtual Nerdcore community have provided infinite space for alternative constructions of identity. In an interview response regarding the online community MC Frontalot stated, "I am very fortunate of the built in 'nerd' support system, I have been able to develop material that's interesting to me without ever having to fake it" (Downing 2011). A "built in nerd support system" is precisely what Nerdcore provides for ostracized and bullied nerds. Nugent described nerd subcultures, like the Nerdcore movement, as safe spaces for nerds to make friends outside the "brutal social hierarchies of school and the office" (Nugent 2007).

Bullying often refers to the "repeated, unprovoked, harmful actions" by one person against another, which may be physical or psychological (Bullock 2002). In their article school bullies, Naylor and Cowie described bullying as "systemic abuse of power, typified by the bully's and victim's inequality of access to power" (Naylor and Cowie 468). Children who are bullied are often anxious, insecure, cautious, and often react through social withdrawal (Bullock 2002). Bullied individuals are often lonely and lack close friendships, and without intervention these individuals are likely "to be bullied repeatedly, putting them at risk for social rejection, depression, and impaired self-esteem" (Bullock 2002).

Psychologist Dr. Robin Rosenberg described the nontraditional approach to social interaction unique to many children labeled "nerds" as a common motive to nerd bullying. Rosenberg stated, “It isn't necessarily that nerds and geeks can't be social, instead, their social interactions don't conform to traditional ones" (Rosenberg 2010). 
The space asserted by "nerds" through nerd counterculture, like Nerdcore, is a way for ostracized youth to come together, share experiences, and build coalitions. David Glanzer, the marketing director for Comic Con, found that nerd conventions and gatherings provide the space needed for geeks to empower each other. He stated, "A lot of people are coming out of their geek closet and proclaiming themselves a nerd, and they are joining together in doing it" (Rosenberg 2010). And not only is the nerd identity reclaimed, unique configurations of nerds have united in their distinct identities. For example, Emptyclosets.com is a virtual space claimed by LGBTQ nerds to mingle and discuss "nerdy" topics.

In his introduction to Why White Kids Love Hip-Hop, Bakari Kitwana discusses how hip-hop provides a voice to the voiceless and "a message of resistance to the status quo" reaching beyond black urban communities and connecting with white audiences in the suburbs (Kitwana xiii). One fan interviewed in the documentary Nerdcore For Life claimed that rap music evolved to encompass more than just voices of marginalized black youth.

You can be yourself and still like rap. Rap isn't exclusively about shooting people and being a gangsta: it's about rhythm... We aren't trying to be or make fun of mainstream hip-hop. We're all trying to preach the gospel of nerd empowerment, spreading nerd pride and nerd love.

This fan's experience with musical narrative emphasizes how Nerdcore attempts to contextualize its own involvement within the history of hip-hop.

\section{Socially Conscious Music Movements}

According to Jason Tanz, Nerdcore is just the most striking example of a trend that has been escalating since the dawn of the millennium: hip-hop without blackness, 
white performers singing in front of almost entirely white audiences about topics and themes that are familiar to their own white lives (Tanz 157). Although the hip-hop magazines and pop charts are still dominated by black musicians, the underground rap scene is "rife with white MCs" (Tanz 157). The assumption is blacks are no longer the necessary variable in the music they created, a music of which black culture is the very foundation (Kitwana 102). Sacha Jenkins, the editorial director of Mass Appeal magazine, worries what will happen if today's white underground artists grow into the next generation of rap stars. "In ten years, it's entirely possible that mainstream rap is $80 \%$ white. There is a real danger in white kids taking over hip-hop and not knowing where this shit comes from... that's what America has a tendency of doing, especially when it comes to the cultures of people of color" (Tanz 176).

White rapper, Macklemore, write a song devoted to the recent white domination of hip-hop music and his own white privilege as a performer. He describes hip-hop as "gentrified" and taken over by white folks, "culturally appropriated by the white face" (Macklemore 2005). The song identifies the ignorance of white privilege as the root cause for white theft of black music:

And we don't want to admit that this is existing So scared to acknowledge the benefits of our white privilege Cause its human nature to want to be part of something different Especially when your ancestors are European Christians And most whites don't want to acknowledge this occurring Cause we got the best deal, the music without the burden Of being black in a system that really wants you to rock Cause all you need is a program and you can go and make hip-hop (Macklemore 2005).

There's an intensive history of white people imitating black culture and eventually consuming and mainstreaming what is specific to black identity. As Bill 
Yousman argues, "Whites' attempt to exert power by purchasing and consuming black culture is a part of the same overall process of the crisis in white identity and retrenchment to white control and domination" (Yousman 375). A similar transition occurred within the history of rock and roll from the white appropriation of black performances to a white domination of music that originated in black culture. The process of white appropriation and domination of marginalized cultures showcases how easy it can be for white youth to adopt signifiers of blackness without suffering the consequences of being black in America (Yousman 387). Yousman argues that white audiences and performers cannot authentically appreciate black culture or hip-hop culture because of the racist drive to consume and dominate (Yousman 375). Sullivan referred to the tendency for white folks to act and think as if all spaces "whether geographical, physical, linguistic, economic, spiritual, bodily, or otherwise" should be available as an unconscious habit of ontological expansiveness (Sullivan 10). White performers and participants in hip-hop culture must remain constantly aware of the cultural history of white supremacy and domination of black culture to successfully authenticate their own involvement in hip-hop.

Kitwana touches on the level of consciousness for white listeners within his interview with Matthew Nelkin, a white fan and performer of hip-hop. Nelkin described going through a crisis after reading Bomb the Suburbs by Billy Wimsatt and considered leaving hip-hop forever. ${ }^{27}$ After debating whether or not he "could represent something that I didn't have the right to represent," Nelkin decided to continue performing rap

\footnotetext{
${ }^{27}$ Bombing the Suburbs was one of the first critiques of white kids and hip-hop. Kitwana quotes Wimsatt's argument: "I' $m$ horrified by the aspect of the white hip-hop thing where you can be a white hardcore underground hip-hop kid in, say Minnesota, and not know a single black person. Their whole social circle is white. Their favorite rappers are white, and they're trying to put out their own CDs, and so on. This is shockingly and violently decontextualized from what hip-hop came from and what it's about."
} 
music. He shared with Kitwana, "To this day, I try to constantly check myself, bearing in mind what it means to be white, to have privilege in America and to take part in hip-hop. I attempt to be as responsible as possible. That's my compromise" (Kitwana 8).

The Nerdcore movement not only provides a space in which nerds can present alternative identities to mainstream and hip-hop ideologies, but also presents a performance of hyperwhiteness that challenges "white" as a natural and unmarked category. Nelkin's consciousness of whiteness and acknowledgement of how his experience is constructed according to his privilege and power is an important concept to apply to Nerdcore performances. The Nerdcore movement has vocalized on different levels a social consciousness I have argued is crucial for an authentic white performance of hip-hop, and there is recognition from within the movement to showcase how Nerdcore is attempting to negotiate a racial awareness of the music. In Nerdcore Rising, fellow band-mate of MC Frontalot describes his own awareness of performing whiteness within a historically black-dominated musical genre:

There's a long history of white people imitating black people and having to do it in a way that gets people to laugh at them because they don't know how to do it with credibility and authenticity... a lot of Nerdcore is attempting to avoid the appropriation of African American creativity without self awareness about it.

Nerdcore rapper Beefy also voiced a similar opinion in his interview from Nerdcore For Life. He described Nerdcore rap as "honest and truthful...I'm not trying to be or make fun of mainstream hip-hop, and we aren't a parody" (Nerdcore For Life). Ultraklystron's interview from Nerdcore For Life spoke to a sense of "realness" or authenticity from a nerd perspective: "If I'm gonna rap about something I might as well be authentic about it, and for me that's rapping about cartoons and anime and comics and computers and nerd culture.... Honesty is a big part of Nerdcore" (Nerdcore For Life). The creators and 
audiences for Nerdcore music have voiced a desire to offer "real" alternative images of race and gender in hip-hop without offending or disrespecting the history of hip-hop as a mode of black cultural production.

Nerdcore rappers often lyrically highlight their various privileges alongside their narratives of ostracization from dominant society. In his song entitled, "First World Problems," MC Fontalot presents a laundry list of "problems" for privileged Americans that emphasize the unequal allocation of power and resources across the world. Among the list of concerns are premature balding, dental visits, lack of television channels, computer malfunctions, treatable sexually transmitted diseases, delayed vacation, etc. Hess continues to showcase his own privileges through his lyrics and musical performances.

Kitwana suggests that white negotiations of historically black musical genres, with specific regards to hip-hop, become spaces in which to build "racial coalitions" (Kitwana 163-210). Kitwana's own definition of the "hip-hop generation" has evolved in his recent work to rethink hip-hop as "a cultural phenomenon beginning as an influential local force in black communities but now captures the imagination of youth across racial, ethnic, and geographic boundaries." ${ }^{28}$ His argument for racial coalitions showcases the influence that an all-encompassing definition of "hip-hop generation" can have on social policy and racial politics. The counterculture of Nerdcore has the potential to merge with the overarching genre of hip-hop to deconstruct whiteness and challenge white privilege.

\footnotetext{
${ }^{28}$ Kitwana, Barkari. Kitwana's 2002 publication, The Hip-Hop Generation, defined the "hip-hop generation" as African Americans born after the civil rights movement between 1965 and 1984. He also discussed the possibility for young African Americans to create a voting bloc_-given the influential black youth culture and its subculture hip-hop.
} 


\section{CHAPTER VI:}

\section{CONCLUSION}

White performances in hip-hop counterculture offer a unique space in which white identity must not only be recognized but purposefully positioned in order to establish authenticity and credibility. The social construction of race is uncharacteristically visible when white racial identity is showcased and emphasized in rap music. Mickey Hess argued that white rappers have positioned their whiteness through immersion, imitation, and inversion in order to achieve success in a genre defined by blackness. The negotiation of nerd identity by Nerdcore rappers and the performance of hyperwhiteness have established a fourth strategy for white authenticity in hip-hop counterculture. The performances of race and gender by nerd rappers subvert cultural norms associated with masculinity and whiteness and establish space for others to perform nonnormative identities. Nerdcore created both a virtual and physical space for nerds to reclaim a pejorative term and build systems of support for counter hegemonic identity performances.

The performances of gender and race enacted by Nerdcore rappers have challenged current mainstream and hip-hop ideologies of both whiteness and masculinity. A socially conscious Nerdcore movement challenges socially unmarked categories of power and privilege and provides a safe arena for counter hegemonic identity performances. Nerdcore's ability to showcase the performativity of socially constructed markers like race and gender disrupt the presumptive naturalness of categories in society. 
But because of the nature of the music, there is a danger of losing the transgressive aspects of Nerdcore if the presentation is viewed as purely parody. The irony and comical value of nerds who rap does risk the mainstream dismissal of the genre and could prevent Nerdcore from revolutionary success in challenging social norms. Nerdcore performers are the first to defend their music and identities; to those involved in the Nerdcore community the genre is not a joke, but a way of negotiating a space in which to perform alternative identities. As long as the Nerdcore counterculture differentiates its own performances from imitation of mainstream hip-hop, it can continue to produce progressive performances of gender and race.

Although Nerdcore has the ability to deconstruct and challenge socially constructed categories, I believe there is further room for analysis. Rap music as an overall genre is male-dominated and Nerdcore does not stray from that stereotype. Only two female artists are commonly mentioned in Nerdcore forums, MC Router and Nursehella, alongside numerous male artists. The identity "nerd" is also typically stereotyped as male, thus female artists in Nerdcore have a unique opportunity to challenge the gendered constructions of nerds as well as rappers. I hope to see more research and work devoted to how self-proclaimed female nerds and Nerdcore rappers challenge socially constructed categories.

Nerdcore also falls into alignment with social stereotypes of "nerd" identity because it lacks the visibility of black nerds. Nerdcore For Life featured only one African American rapper, Nomad, who received marginal coverage and minimal discussion. According to Ron Eglash's research on the racial and sexual construction of nerd identity, the black nerd image contradicts social constructions of black masculinity and challenges 
current racial ideologies (Eglash 59). Although African American self-identified "nerd" rap performances was outside the scope of this project, black nerd artists are growing in numbers and in demand. In 2010, a coalition of African American activists and scholars released a statement citing the urgent need for popular media to depict a new black nerd archetype that accurately reflects the "full spectrum of $21^{\text {st }}$ century dorkdom" ("AfricanAmerican Community Calls for New Black Nerd"). The official statement said, "Nerds in the African American continue, like their predecessors to be socially awkward, hilariously unstylish, and a source of embarrassment for their cooler black friends. But a recent survey of pop-cultural archetypes found that in the current TV lineup, almost all nerds are white" ("African American Community Calls for New Black Nerd"). Within a discussion of alternative performances of blackness, CNN specialist, Mekeisha Madden Toby, referenced the growing numbers of African American intellectuals that self identifying as black nerds, or "blerds" (Toby 2012). Future research could further analyze African American "blerds" and the potential to challenge stereotypical blackness both in dominant ideology and hip-hop culture.

Nerdcore rap has not attempted to assimilate into mainstream hip-hop culture, nor has it conformed to dominant ideologies of race and gender. The counterculture developed through Nerdcore music successfully developed a space in which selfproclaimed nerds can challenge current constructions of gender and race and offer alternative performances to the masses. The Nerdcore community's social consciousness and respect for the history of hip-hop has developed the genre into a transgressive venue for challenging mainstream ideologies. 


\section{REFERENCES}

"African American Community Calls for New Black Nerd". The Onion Online. 46.44 (4 November 2010). < http://www.theonion.com/articles/africanamericancommunity-calls-for-new-black-nerd,18389/>

Alcoff, Linda. "Philosophy and Racial Identity". Philosophy Today. 41.1 (Spring 1997). $67-76$.

Anderegg, David. Nerds: How Dorks Dweebs, Techies, and Trekkies Can Save America, and Why They Might Be Our Last Hope. New York: Penguin Group, 2011.

Baldwin, James. “On Being White... And Other Lies”. Essence. (April 1984). 90-92.

Bishop, John H., Matthew Bishop, Lara Gelbwasser, Shanna Green, Andrew Zuckerman, Amy Ellen Schwartz, and David F Labaree. "Nerds and Freaks: A Theory of Student Culture and Norms." Brooking Papers on Education Policy. 6 (2003) 141213.

Boas, Franz. "The Instability of Human Types". Papers on Interracial Problems Communicated to the First Universal Races Congress Held at the University of London, July 26-29. Ed. Gustav Spiller. Boston: Ginn and Co., 1912. 99-103.

Brod, Harry. "Studying Masculinities as Superordinate Studies". Masculinity Studies \& Feminist Theory. Ed. Judith Kegan Gardiner. New York: Columbia University Press, 2002.

Bucholtz, Mary. "You Da Man: Narrating the Racial Other in the Production of White Masculinity". Journal of Sociolinguistics. 3/4. (1999). 443-460.

- . "The Whiteness of Nerds: Superstandard English and Racial Markedness". Journal of Linguistic Anthropology. 11.1 (2001). 84-100.

Bullock, Janis R. "Bullying Among Children”. Childhood Education. 78.3 (Spring 2002)

Caro, Robert. The Power Broker: Robert Moses and the Fall of New York. New York: Vintage Books, 1975.

Chang. Jeff. Can't Stop Won't Stop: A History of the Hip-hop Generation. New York: St. Martin's Press, 2005.

Chappell, Kevin "How Blacks Invented Rock and Roll: R\&B Stars Created Foundations 
of Multibillion-Dollar Music Industry”. Ebony. (Jan 1997) 52.54.

Cheney, Charise. "Ladies First?: Defining Manhood in the Golden Age of Rap

Nationalism". Brothers Gonna Work it Out: Sexual Politics in the Golden Age of Rap Nationalism. New York: New York University Press, 2006.

Cohen, Judah. "Hip-Hop Judaica: The Politics of Representin' Heebster Heritage". Popular Music. 28.1 (2009) 1-18.

Davis, David Brion. Inhuman Bondage: The Rise and Fall of Slavery in the New World. New York \& Oxford: Oxford University Press, 2006.

Dimitriadis, Greg. Performing Identity/Performing Culture: Hip Hop as Text, Pedagogy, and Lived Practice. New York: Peter Lang, 2001.

Downing, Andy. "Nerdcore Rapper MC Frontalot Says It's All Geek to Him". McClatchy- Tribune Business News. 16 Aug. 2011.

Eglash, Ron. "Race, Sex, and Nerds: From Black Geeks to Asian American Hipsters". Social Text. 20.2 (Summer 2002). 49-62

Ehlerss, Nadine. "Retroactive Phantasies: Discourse, Discipline, and the Production of Race". Social Identities. 14.3 (May 2008) 333-347.

Eminem. Lyrics. "Bonnie and Clyde". Music by Marshall Mathers. The Slim Shady LP. CD. 1999.

—. Lyrics. "Stay Wide Awake”. Music by Marshall Mathers. Relapse. CD. 2009.

Faiola, Anthony. "Geek Pride Blooms Into a Real-World Subculture". The Washington Post. (July 2007).

Foster, Gwendolyn Audrey. Performing Whiteness: Postmodern Re/constructions in the Cinema. Albany: State of New York Press, 2003.

Frankenberg, Ruth. "The Mirage of Unmarked Whiteness". The Making and Unmaking of Whiteness: Eds. Birgit Brander Rasmussen, Eric Klineneberg, Irene J. Nexica, and Matt Wray. Durham \& London: Duke University Press, 2001.

Fredrickson, George M. Racism: A Short History. Princeton \& Oxford: Princeton University Press, 2002.

Grealy, Liam. "Negotiating Cultural Authenticity in Hip-Hop: Mimicry, Whiteness and Eminem". Continuum: Journal of Media \& Cultural Studies. 22.6 (December 2008). 851-865. 
Gross, Josh. "M.C. Frontalot.. Boise Weekly. (31 Aug. 2011). p. 27.

Harper, Phillip Brian. Are We Note Men?: Masculine Anxiety and the Problem of African American Identity. New York \& Oxford: Oxford University Press, 1996.

Hess, Mickey. "Hip-Hop Realness and the White Performer". Critical Studies in Media Communication. 22.5 (2005): 372-389.

-. Is Hip-hop Dead?: The Past, Present, and Future of America's Most Wanted Music. London \& Westport: Praeger, 2007.

Hip-Hop: Beyond Beats \& Rhymes. Dir. Byron Hurt. 2006. Film.

hooks, bell. Black Looks: Race and Repression. Boston: South End Press, 1992.

Hunter, Rosamund. "Carmen Ashurst Discusses the Music Industry." Re/Visionist Online.15 March 2010. Web. 1 March 2012.

Huxley, Julian S. and A.C. Haddon. We Europeans: A Survey of 'Racial' Problems. New York: Kraus, 1970.

Ice T. Lyrics. “Squeeze the Trigger”. Music by Tracy Marrow. Rhyme Pays. CD. 1987

Jordan, Winthrop D. White Over Black: American Attitudes Toward the Negro, 15501812. Chapel Hill: The University of North Carolina Press, 1968.

Katz, Jason. "When You're Asked About Eminem". Jackson Katz Online Publications. (2001). <http://www.jacksonkatz.com/pub_eminem.html>

Kimmel, Michael. Manhood in America: A Cultural History. New York \& Oxford: Oxford Press, 2006.

—. Guyland: The Perilous World Where Boys Become Men. New York: Harper Collins, 2009.

Kelley, Norman. "Notes on the Political Economy of Black Music". Rhythm and Business: The Political Economy of Black Music. New York: Akaschic Books, 2002.

Kelley, Robin D.G. Droppin' Science. Ed. William Eric Perkins. Philadelphia: Temple University Press, 1996. 117-158.

Kendall, Lori. "Geeks May Be Chic, But Negative Nerd Stereotype Still Exist". Science Daily Online.3 March 2009. <http://www.sciencedaily.com/releases/2009/03/090303123810.htm> 
- . "Nerd Nation: Images of Nerds in US Popular Culture". International Journal of Cultural Studies. 2.2 (1999). 260-283.

- "'White and Nerdy': Computers, Race, and Nerd Stereotype". The Journal of Popular Culture. 44.3 (2011) 505-524.

Leavy, Patricia Lina. "The Feminist Practice of Content Analysis". Feminist Research Practice. Eds. Sharlne Nagy Hesse-Biber and Patricia Lina Leavy. London: Sage Publications, 2007.

Levi-Strauss, Claude. Race and History. Paris: Unesco, 1952.

Lommel, Cookie. The History of Rap Music. Philadelphia: Chelsea House Publishers, 2001.

Lott, Eric. Love and Theft: Blackface Minstrelsy and the American Working Class. New York \& Oxford: Oxford University Press, 1993.

"Lukifer". "In Defense of Nerdcore". Lukifer Blog Online. 9 July 2009. Web. 1 March 2012. < http://lukifer.net/blog/in_defense_of_nerdcore>.

Macklemore Lyrics. "White Privilege". Music by Ben Haggerty. The Language of My World by Macklemore. CD. 2005.

MC Chris. Lyrics. "Evergreen". Music by Christopher Ward. Eating Is Not Cheating. CD. 2005.

MC Frontalot. Lyrics. “Crime Spree”. Music by Damian Hess. Nerdcore Rising. CD. 2005.

—. Lyrics. "I Heart Fags". Music by Damian Hess. Nerdcore Rising. CD. 2005

McIntosh, Peggy. "White Privilege: Unpacking the Invisible Knapsack". Peace and Freedom. (July/August 1989). 10-12.

McLeod, Kembrew. "Authenticity Within Hip-Hop and Other Cultures Threatened with Assimilation". Journal of Communication (Autumn 1999). 134-150.

Mills, Charles. The Racial Contract. Ithaca \& London: Cornell University Press, 1997.

Nakayama, Thomas K. and Robert L Krizek. "Whiteness: A Strategic Rhertoric". Quarterly Journal of Speech. 81 (1995). 291-309.

Naylor, Paul and Helen Cowie. "The Effectiveness of Peer Support Systems in 
Challenging School Bullying: The Perspectives and Experiences of Teachers and Pupils". Journal of Adolescence. 22 (1999) 467-479.

Nerdcore For Life. Dir. Dan Lamoureux. 2008. Film.

Nerdcore Rising. Dir. Negin Farsad and Kim Gatewood. 2008. Film.

Nugent, Benjamin. "Field Guide to the Nerd: It's All Geek to Me". Psychology Today Online. 1 July 2008. Web. 1 March 2012.

Nugent, Benjamin. "Who's a Nerd Anyway?" The New York Times Online. 29 July 2007. Web. 1 March 2012.

N.W.A. Lyrics. "Fuck the Police”. Music by O'Shea Jackson and Lorenzo Jerald Patterson. Straight Outta Compton. CD. 1988.

Ogbar, Jeffrey Ogbonna Green. Hip-Hop Revolution: The Culture and Politics of Rap. Lawerence: University of Kansas Press, 2007.

Ogg, Alex. The Hip-hop Years: A History of Rap. New York: From International, 2001.

Omi, Michael and Howard Winant. Racial Formation in the United States: From the 1960s to the 1990s. New York \& London: Routledge, 1994.

Owen, David. "Reproducing Whiteness". The White Privilege Conference. Albuquerque, NM. 30 March 2012.

Perkins, William Eric. “The Rap Attack: An Introduction”. Droppin' Science. Ed. William Eric Perkins. Philadelphia: Temple University Press, 1996. 1-48.

Perry, Imani. Prophets of the Hood: Politics and Poetics in Hip-Hop. Durham \& London: Duke University Press, 2004.

Phinney, Kevin. Souled American: How Black Music Transformed White Culture. New York: Billboard Books, 2005.

Pough, Gwendolyn. Check It While I Wreck It. Boston: Northeastern University Press, 2004.

Powell, Catherine Tabb. "Rap Music: An Education with a Beat from the Street". The Journal of Negro Education 60.3 (Summer 1991) 245-259.

Rasmussen, Birgit Brander, Eric Klinenberg, Irene J. Nexica, and Matt Wray. 
"Introduction". The Making and Unmaking of Whiteness. Eds. Birgit Brander Rasmussen, Eric Klineneberg, Irene J. Nexica, and Matt Wray. Durham \& London: Duke University Press, 2001.

Rose, Tricia. Black Noise: Rap Music and Black Culture in Contemporary America. Hanover: Wesleyan University Press, 1994.

-. The Hip Hop Wars: What We Talk About When We Talk About Hip-Hop—and Why It Matters. New York: Basic Civitas Books, 2008

Rosenberg, Robin S. "Comic-Con: Nerd and Geek Community: Community is Important to Everyone-Including Nerds and Geeks". Psychology Today Online. 6 August 2010. < http://www.psychologytoday.com/blog/the-superheroes/201008/comiccon-nerd-and-geek-community>

Schroeder, Suheyla Kirca. "A Methodological Approach to the Study of Feminism and Popular Culture: The Case of Women's Magazines". Feminist Research Practice. Eds. Sharlne Nagy Hesse-Biber and Patricia Lina Leavy. London: Sage Publications, 2007.

Sellnow, Deanna and Timothy Sellnow. "The 'Illusion of Life' Rhetorical Perspective: An Integrated Approach to the Study of Music as Communication". Critical Studies in media Communication. 18.4 (December 2001) 395-415.

Shuker, Roy. Understanding Popular Music. London \& New York: Routledge, 1994.

Strausbaugh, John. Black Like You: Blackface, Whiteface, Insult \& Imitation in American Popular Culture. New York: Penguin Group, 2006.

Steingberg, Laurenace, Bradford Brown, and Sandford Dornbusch. Beyond the Classroom: Why School Reform Has Failed and What Parents Need to Do. New York: Simon \& Schuster, 1996.

Sullivan, Shannon. Revealing Whiteness: The Unconscious Habits of Racial Privilege. Bloomington: Indiana University Press, 2006.

Tanz, Jason. Other People's Property: A Shadow History of Hip-hop in White America. New York: Bloomsbury, 2007.

Tate, Greg. Everything But the Burden: What White People are Taking From Black Culture. Ed. Greg Tate. New York: Broadway Books, 2003.

Toby, Mekeisha Madden. "The Rise of the Black Nerd in Pop Culture". CNN Online. 31 March 2012. < http://www.cnn.com/2012/03/31/showbiz/rise-of-blacknerds/index.html> 
Warren, John T. "Doing Whiteness: On the Performative Dimension of Race in the Classroom". Communications Education. 50.2 (April 2001) 91-108

White, Armond. "Who Wants to See Ten Niggers Play Basketball?" Droppin' Science.

Ed. William Eric Perkins. Philadelphia: Temple University Press, 1996. 192-210.

Winant, Howard. The New Politics of Race: Globalism, Difference, Justice. Minneapolis \& London: University of Minnesota Press, 2004.

-.The World is a Ghetto: Race and Democracy Since World War II. New York: Basic Books, 2001.

Wise, Time. Colorblind: The Rise of Post-Racial Politics and the Retreat from Racial Equity. San Francisco: City Lights Books, 2010.

Wray, Matt and Newitz, Annalee. "Introduction". White Trash: Race and Class in America. Eds. Matt Wray and Annalee Newitz. New York \& London: Routledge, 1997.

“Xuntra". "MC Lars: Nerdcore is Dead?" MC Frontalot Forum. 9 July 2009. Web. 1 March 2012. <http://frontalot.com/bbs/viewtopic.php?t=2621\&start=20>

Yousman Bill. "Blackophilia and Blackophobia: White Youth, the Consumption of Rap Music, and White Supremacy". Communication Theory. 13.4. (2003): 366-391.

Zack, Naoimi. Philosophy of Science and Race. New York \& London: Routledge, 2002. 


\title{
CURRICULUM VITAE
}

\author{
Jessica Elizabeth Ronald \\ Jessir2442@gmail.com \\ 502.807.1055
}

Education and Research

University of Louisville, Louisville, $K Y$

MA, Pan African Studies:

Graduate Certificate, Latin American Studies

2012 (anticipated)

MA, Women's and Gender Studies

2011

University of Kentucky, Lexington, $\mathrm{KY}$

2008

2003-2007

\section{Conference Presentations and Workshops}

"I'm Not a Racist, But...: Challenging White Privilege on Our Campus"

Presenter 2012

Inclusion and Diversity Workshop, University of Louisville

"I'm Not a Racist, But...: Challenging White Privilege on College Campuses"

Presenter 2012

The White Privilege Conference: Albuquerque, New Mexico

"Inclusion and Equity for Jefferson County Public School Students"

Jefferson County Public School Workshop for Diversity: Louisville, $\mathrm{KY}$

The White Privilege Conference Symposium

White Privilege Workshop: University of Colorado, Colorado Springs, co

"Alternative Performances of Masculinity in Music: The Counterculture of Nerdcore" American Men's Studies Association Conference, Kansas City, MO

"Teaching Masculinities in a Post-American World: a Global Perspective"

American Men's Studies Workshop, Kansas City, MO

"Beyond Binaries: Identity and the Sexuality Spectrum" Workshop with Robyn Ochs: University of Louisville, Louisville, $K Y$

"Alternative Performances of Gender and Race in Hip Hop Music" International Association for the Study of Popular Music Conference

"Performativity of Race and Gender in Music: The Hip Hop Subculture of Nerdcore" National Council for Black Studies Conference 2010, New Orleans, LA

"Potential Feminist Performances of Masculinity in Music" Women's History Month Conference: Sarah Lawrence College, Yonkers, NY

Presenter 2012

Facilitator 2011

Presenter 2011

Participant 2011

Participant 2011

Presenter 2010

Presenter 2010

Presenter 2010

\section{Awards and Honors}

Graduate Assistantship, Louisville Debate Society, University of Louisville, 2011-2012 Lilialyce Akers Travel/Research Awards for Study of Women \& Global Issues, University of Louisville, 2011 International Graduate Student Scholarship Travel Grant, University of Louisville, 2011 Tachau Scholarship for Graduate Work in Women's and Gender Studies, University of Louisville, 2009/2010 Women's and Gender Studies Travel Scholarship for Graduate Research, University of Louisville, 2010

\section{Teaching Experience}

Substitute Teacher, Jefferson County Public Schools

2011-Present Louisville, Kentucky

Graduate Teaching \& Coaching Assistant, Malcolm X Debate Society 


\author{
University of Louisville \\ Teaching Assistant COM 319: Debate (Mudd) \\ University of Louisville
}

Languages and Travel

University of Louisville Study Abroad Program:

University of West Indies, Trinidad/Tobago 2011

Belize, Mexico, \& Honduras: Personal Travel

2011

Jamaica: Personal Travel

2010

Ireland, Scotland, \& England: Personal Travel

2010

Dominican Republic: Personal Travel

\section{Activities and Volunteer Work}

Intern, Inclusion and Equity Program

International, Diversity, and Outreach, University of Louisville

Ambassador, Graduate Teaching Academy

School of Interdisciplinary and Graduate Studies, University of Louisville

Volunteer, Graduate Peer Mentors Program

University of Louisville

Activist, White Spaces Postgraduate Network

Worldwide Universities Network

Chair of Campus Activities \&Philanthropy, Women 4 Women Student Chapter University of Louisville

Volunteer, No Kill Louisville: Transport Assistant Louisville, $K Y$

Activist, PGSA: Pan African Graduate Student Association

University of Louisville

Activist, P.E.A.C.C.: Prevention, Education, and Advocacy on Campus and in the Community University of Louisville

Assistant Director/Actress, The Vagina Monologues

University of Louisville

Actress, A Memory, A Monologue, A Rant, and a Prayer

University of Louisville

Activist, S.E.E.D.S.: Students Educating and Empowering for Domestic Safety University of Kentucky

Activist, S.T.A.G.: Students Taking Action Globally

University of Kentucky

Volunteer, Habitat for Humanity: UK Student Branch University of Kentucky

Intern, American Cancer Society

Lexington, $\mathrm{KY}$

\section{Other Professional Experience}

Director of Sales, Pure Romance

Providing space for female empowerment and education with regards to sexuality Family Nanny

Educating and entertaining twin boys throughout adolescence

Joseph Beth Booksellers

August 2011-Present

August 2011-Present

August 2011- Present

May 2011-Present

April 2011- Present

August 2011- Present

August 2010-Present

August 2008-Present

$2009 / 2010$

2008

2006-2007

2005-2007

2005-2007

2005-2006

June 2008-Present

May 2004-Present

Aug 2005- May 2006 